\title{
FY20 Progress Report on Sodium Exposure Tests of A709 Steel
}

Nuclear Science and Engineering Division 


\begin{abstract}
About Argonne National Laboratory
Argonne is a U.S. Department of Energy laboratory managed by UChicago Argonne, LLC under contract DE-AC02-06CH11357. The Laboratory's main facility is outside Chicago, at 9700 South Cass Avenue, Argonne, Illinois 60439. For information about Argonne and its pioneering science and technology programs, see www.anl.gov.
\end{abstract}

\title{
DOCUMENT AVAILABILITY
}

Online Access: U.S. Department of Energy (DOE) reports produced after 1991 and a growing number of pre-1991 documents are available free at OSTI.GOV (http://www.osti.gov/), a service of the US Dept. of Energy's Office of Scientific and Technical Information.

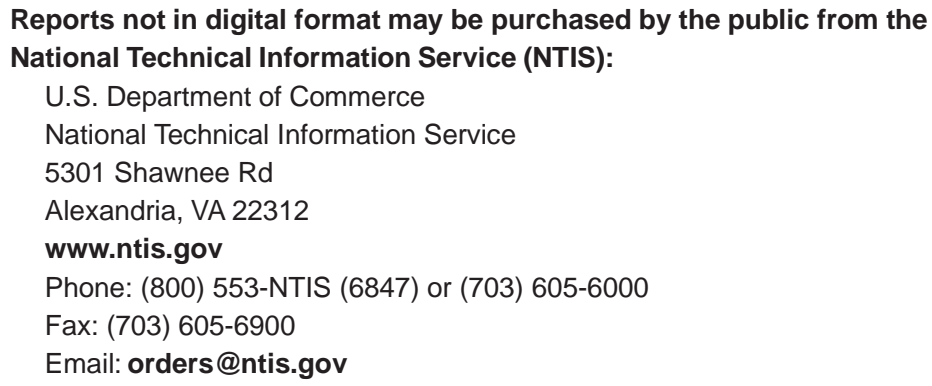

Reports not in digital format are available to DOE and DOE contractors from the Office of Scientific and Technical Information (OSTI):

U.S. Department of Energy

Office of Scientific and Technical Information

P.O. Box 62

Oak Ridge, TN 37831-0062

www.osti.gov

Phone: (865) 576-8401

Fax: (865) 576-5728

Email: reports@osti.gov

\section{Disclaimer}

This report was prepared as an account of work sponsored by an agency of the United States Government. Neither the United States Government nor any agency thereof, nor UChicago Argonne, LLC, nor any of their employees or officers, makes any warranty, express or implied, or assumes any legal liability or responsibility for the accuracy, completeness, or usefulness of any information, apparatus, product, or process disclosed, or represents that its use would not infringe privately owned rights. Reference herein to any specific commercial product, process, or service by trade name, trademark, manufacturer, or otherwise, does not necessarily constitute or imply its endorsement, recommendation, or favoring by the United States Government or any agency thereof. The views and opinions of document authors expressed herein do not necessarily state or reflect those of the United States Government or any agency thereof, Argonne National Laboratory, or UChicago Argonne, LLC. 


\section{FY20 Progress Report on Sodium Exposure Tests of A709 Steel}

Prepared by

Meimei Li

Nuclear Science and Engineering Division

Argonne National Laboratory

September 2020 


\section{ABSTRACT}

Sodium exposure tests were conducted on the first commercial heat, H58776 of A709 steel. Six different processing and heat treatment conditions were investigated, including three processing conditions, namely, Argon-Oxygen-Decarburization (AOD), Electro-slag Remelting (ESR), and Electro-slag Remelting with subsequent homogenization (HOMO), and two heat treatment conditions, i.e. solution annealing at $1100^{\circ} \mathrm{C}\left(\mathrm{SA} 1100^{\circ} \mathrm{C}\right)$ or $1150^{\circ} \mathrm{C}\left(\mathrm{SA} 1150^{\circ} \mathrm{C}\right)$. Specimens of AOD-SA $1100^{\circ} \mathrm{C}$, AOD-SA $1150^{\circ} \mathrm{C}$, ESR-SA $1100^{\circ} \mathrm{C}$, ESR-SA $1150^{\circ} \mathrm{C}, \mathrm{HOMO}-\mathrm{SA} 1100^{\circ} \mathrm{C}$, and $\mathrm{HOMO}-\mathrm{SA} 1150^{\circ} \mathrm{C}$ were tested in sodium at $650^{\circ} \mathrm{C}$ and for times up to $10,152 \mathrm{~h}$. Specimens in the AOD-SA $1100^{\circ} \mathrm{C}$ and AOD-SA $1150^{\circ} \mathrm{C}$ conditions were also tested in sodium at 550 and $600^{\circ} \mathrm{C}$. Parallel thermal aging experiments were carried out for comparison with sodium exposure tests to separate the thermal and sodium effects. It was found that

- A709 H58776 generally showed a weight loss after sodium exposures at $650^{\circ} \mathrm{C}$ except a few data points of the ESR-SA $1100^{\circ} \mathrm{C}$ specimens. The corrosion rate showed large variations in the initial stage and decreased with increasing exposure time. Long-term exposure tests are needed to determine its steady-state corrosion rate.

- The AOD-SA $1100^{\circ} \mathrm{C}$ and HOMO-SA $1100^{\circ} \mathrm{C}$ specimens showed similar tensile responses after thermal or sodium exposures at $650^{\circ} \mathrm{C}$. The yield stress increased, the ultimate tensile strength decreased, and the uniform and total elongations were reduced after thermal or sodium exposures. A longer exposure time had a minimal effect on the tensile strength but further reduced the tensile ductility. The sodium-exposed specimens had higher tensile strength than the thermally-aged specimens. In contrast, the ESR-SA $1100^{\circ} \mathrm{C}$ specimens showed an increase in the yield stress and the ultimate tensile strength after thermal or sodium exposures at $650^{\circ} \mathrm{C}$ and $\sim 10,000 \mathrm{~h}$.

- The AOD-SA $1150^{\circ} \mathrm{C}$ and ESR-SA $1150^{\circ} \mathrm{C}$ specimens showed similar tensile behavior after thermal or sodium exposures at $650^{\circ} \mathrm{C}$. Thermal or sodium exposures at $650^{\circ} \mathrm{C}$ increased the yield stress, decreased the ultimate tensile strength, and reduced uniform and total elongations. There were minimal differences in tensile properties between the sodium-exposed and thermally-aged specimens after an $\sim 3000 \mathrm{~h}$ exposure. After an exposure for $\sim 10,000 \mathrm{~h}$ the sodium-exposed specimens showed higher yield stress and ultimate tensile strength and lower uniform and total elongations than the thermally-aged specimens. For the HOMO-SA $1150^{\circ} \mathrm{C}$ specimens, thermal or sodium exposures at $650^{\circ} \mathrm{C}$ significantly increased the yield stress but had a minimal effect on the ultimate tensile strength. Both uniform and total elongations were significantly reduced at an exposure time of $\sim 3,000 \mathrm{~h}$, and they were further reduced after an exposure of $\sim 10,000 \mathrm{~h}$. The sodium-exposed specimens had lower tensile ductility than the thermally-aged specimens.

- Before exposure, the stress-strain curves of the specimens in all six processing-heat treatment conditions showed serrations indicating the dynamic aging effect at $650^{\circ} \mathrm{C}$. Thermal aging or sodium exposures at $650^{\circ} \mathrm{C}$ after $\sim 10,000 \mathrm{~h}$ completely removed the serrations of the flow curves in A709 H58776, indicating strong precipitation during thermal or sodium exposures.

Longer-term sodium exposure tests are needed to determine the steady-state corrosion rates in sodium for A709 H58776 and fully understand the influence of sodium exposures on its mechanical performance. 


\section{TABLE OF CONTENTS}

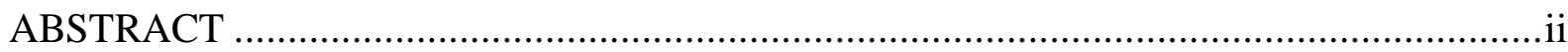

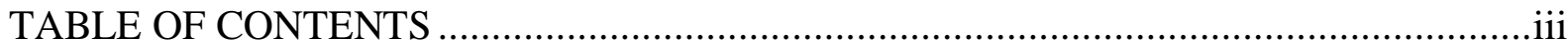

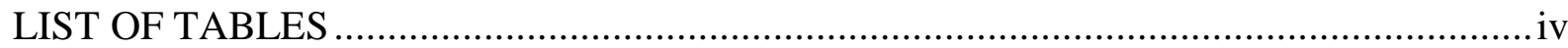

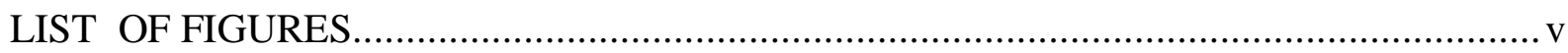

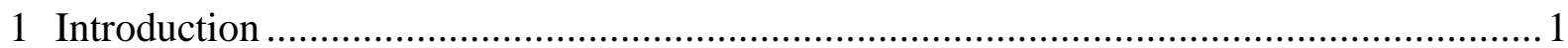

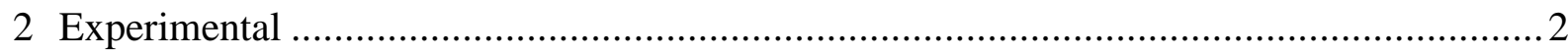

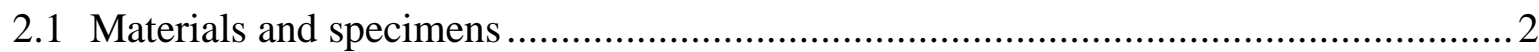

2.2 Forced convection sodium loops ............................................................................ 3

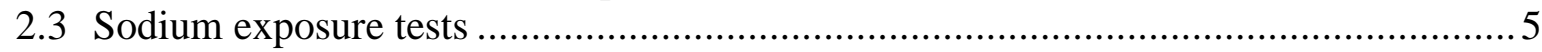

2.4 Thermal aging tests.....................................................................................

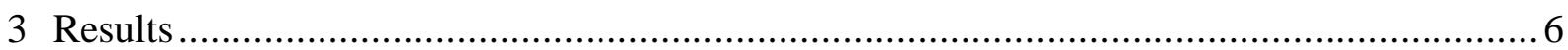

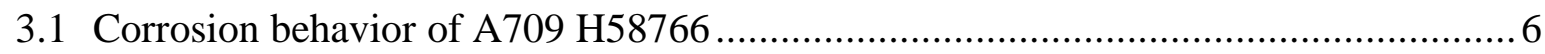

3.2 Effect of sodium exposure on tensile properties of A709 H58776 ……...................... 7

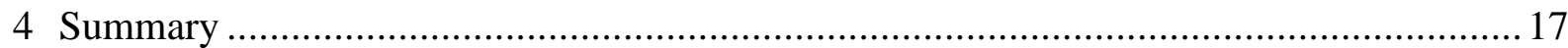

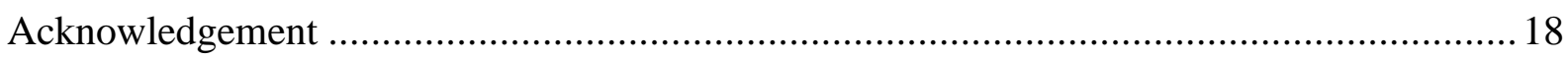

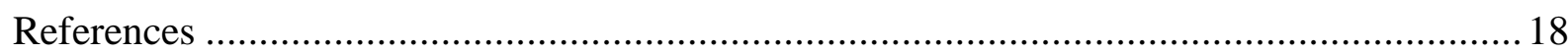




\section{LIST OF TABLES}

Table 1. Chemical composition of melt of A709 first commercial heat H58776 (wt\%) .... 2

Table 2. Processing-heat treatment conditions of A709 H58776 examined in this work ... 2

Table 3. Tensile properties of A709 $\mathrm{H} 58776$ after sodium or thermal exposures at $650^{\circ} \mathrm{C} 10$ 


\section{LIST OF FIGURES}

Figure 1. Schematic drawing of subsize sheet-type tensile specimens (unit: in)................... 3

Figure 2. Isometric view of (a) the Sodium Materials Test Loop 1 (SMT-1) and (b) the Sodium Materials Test Loop 2 (SMT-2)............................................................. 4

Figure 3. Corrosion rate as a function of $\mathrm{Na}$ exposure time at $650^{\circ} \mathrm{C}$ for $\mathrm{A} 709 \mathrm{H} 58776$ in six different processing-heat treatment conditions ......................................... 7

Figure 4. Stress-strain curves for the AOD-SA $1100^{\circ} \mathrm{C}$ specimens (a) before exposure, after thermal exposure at $650^{\circ} \mathrm{C}$ for $3,144 \mathrm{~h}$, and after sodium exposures at $650^{\circ} \mathrm{C}$ for $3,336 \mathrm{~h}$; (b) before exposure, after thermal exposure at $650^{\circ} \mathrm{C}$ for $10,056 \mathrm{~h}$, and after sodium exposures at $650^{\circ} \mathrm{C}$ for $10,152 \mathrm{~h}$

Figure 5. Stress-strain curves for the ESR-SA $1100^{\circ} \mathrm{C}$ specimens (a) before exposure, after thermal exposure at $650^{\circ} \mathrm{C}$ for $3,144 \mathrm{~h}$, and after sodium exposures at $650^{\circ} \mathrm{C}$ for $3,336 \mathrm{~h}$; (b) before exposure, after thermal exposure at $650^{\circ} \mathrm{C}$ for $10,056 \mathrm{~h}$, and after sodium exposures at $650^{\circ} \mathrm{C}$ for $10,152 \mathrm{~h}$

Figure 6. Stress-strain curves for the HOMO-SA $1100^{\circ} \mathrm{C}$ specimens (a) before exposure, after thermal exposure at $650^{\circ} \mathrm{C}$ for $3,144 \mathrm{~h}$, and after sodium exposures at $650^{\circ} \mathrm{C}$ for $3,336 \mathrm{~h}$; (b) before exposure, after thermal exposure at $650^{\circ} \mathrm{C}$ for $10,056 \mathrm{~h}$, and after sodium exposures at $650^{\circ} \mathrm{C}$ for $10,152 \mathrm{~h}$

Figure 7. Stress-strain curves for the AOD-SA $1150^{\circ} \mathrm{C}$ specimens (a) before exposure, after thermal exposure at $650^{\circ} \mathrm{C}$ for $3,144 \mathrm{~h}$, and after sodium exposures at $650^{\circ} \mathrm{C}$ for $3,336 \mathrm{~h}$; (b) before exposure, after thermal exposure at $650^{\circ} \mathrm{C}$ for $10,056 \mathrm{~h}$, and after sodium exposures at $650^{\circ} \mathrm{C}$ for $10,152 \mathrm{~h}$

Figure 8. Stress-strain curves for the ESR-SA $1150^{\circ} \mathrm{C}$ specimens (a) before exposure, after thermal exposure at $650^{\circ} \mathrm{C}$ for $3,144 \mathrm{~h}$, and after sodium exposures at $650^{\circ} \mathrm{C}$ for $3,336 \mathrm{~h}$; (b) before exposure, after thermal exposure at $650^{\circ} \mathrm{C}$ for $10,056 \mathrm{~h}$, and after sodium exposures at $650^{\circ} \mathrm{C}$ for $10,152 \mathrm{~h}$

Figure 9. Stress-strain curves for the HOMO-SA $1150^{\circ} \mathrm{C}$ specimens (a) before exposure, after thermal exposure at $650^{\circ} \mathrm{C}$ for $3,144 \mathrm{~h}$, and after sodium exposures at $650^{\circ} \mathrm{C}$ for $3,336 \mathrm{~h}$; (b) before exposure, after thermal exposure at $650^{\circ} \mathrm{C}$ for $10,056 \mathrm{~h}$, and after sodium exposures at $650^{\circ} \mathrm{C}$ for $10,152 \mathrm{~h}$

Figure 10. Comparison of yield stress, ultimate tensile strength, uniform elongation and total elongation for $1100^{\circ} \mathrm{C}$-solution-annealled A709 H58776 15

Figure 11. Comparison of yield stress, ultimate tensile strength, uniform elongation and total elongation for $1150^{\circ} \mathrm{C}$-solution-annealled A709 $\mathrm{H} 58776$ 


\section{Introduction}

The Advanced Reactor Technologies campaign has focused on the sodium-cooled fast reactor (SFR) concept because of its technical maturity. SFRs are also a leading candidate for recycling used fuel to close the fuel cycle. The current needs are for more reliable, more flexible, and more economical reactors suitable for commercial nuclear power generation. Research and development addresses three main areas, including advanced materials, innovative designs of components and systems, and computer modeling and simulation. Advanced Materials Development Campaign focuses on developing and qualifying high-performance advanced materials and understanding and predicting long-term performance of reactor structural materials exposed to the sodium coolant at elevated temperatures.

Advanced materials are a critical element in the development of next-generation SFRs. Enhanced materials performance not only improves safety margins for component performance and provides design flexibility but is also essential for the economics of advanced SFRs. In general, austenitic stainless steels are used for in-core structural components, piping, and intermediate heat exchanger. High chromium ferritic steels are considered for primary piping system, intermediate heat exchanger, secondary piping and steam generator in SFRs. The selection of a particular material and combinations that will be used in both primary and secondary systems is based upon a number of factors. For in-core or out-of-core applications, the stability of the material in the fast neutron environment, compatibility with the sodium coolant and elevated temperature performance are of primary concern. Degradation due to high temperature and irradiation damage are common issues to all types of reactor materials, while environmental degradation in liquid sodium is unique to SFR materials.

Structural materials can undergo a variety of interactions upon exposure to liquid sodium. The interactions can be broadly classified into metallic and nonmetallic element transfer. Metallic element transfer is a solution process of a solid metal in liquid sodium. It can cause dissolution of metallic elements into sodium, or by formation of corrosion products on the metallic surfaces that subsequently erode/spall into the flowing sodium. Metallic element mass transfer usually establishes a go/no-go type of evaluation of an alloy for use as a structural material in a sodium environment. Nonmetallic elements, such as oxygen, carbon, nitrogen, and hydrogen, are known to migrate in structural material/sodium systems under both isothermal and non-isothermal conditions as a result of chemical activity differences. Transfer of these elements also occurs in systems where combinations of materials of different composition are used. From the operation of the SFR standpoint, the oxygen impurity in sodium can be controlled to $\sim 1 \mathrm{wppm}$ which would result in acceptable corrosion of ferrous alloys at the typical operating temperature. The solubility of nitrogen in sodium is low at SFR operating temperatures and its effect on the materials performance may not be significant. On the other hand, carbon transfer in materials-sodium systems can result in carburization or decarburization in an alloy, causing microstructural instability and degradation of its mechanical performance which ultimately affect the lifetime of reactor components. Carbon transfer is a dynamic process varying from systems to systems and cannot be effectively controlled. The influence of carbon in sodium on the microstructure and mechanical properties of structural materials is a major concern for their applications in SFRs. 
The goal of this program is to evaluate and understand the influence of sodium exposures on the microstructure and mechanical properties of an advanced austenitic stainless steel, A709. This report presents corrosion and tensile test data of A709 first commercial heat, H58776 after sodium and thermal exposures at $650^{\circ} \mathrm{C}$ for $\sim 10,000 \mathrm{~h}$.

\section{Experimental}

\subsection{Materials and specimens}

Sodium exposure tests were conducted on the first commercial heat 58776 (H58776) of A709 steel. The product chemistry of the heat is given in Table 1. It conforms to the alloy specifications. The melt procedure involved three different processing conditions, namely, ArgonOxygen-Decarburization (AOD), Electro-slag Remelting (ESR), and Electro-slag Remelting with subsequent homogenization (HOMO). Two different heat treatments were conducted on AOD, $\mathrm{ESR}$, or HOMO-processed materials, namely, solution annealed at $1100^{\circ} \mathrm{C}\left(\mathrm{SA} 1100^{\circ} \mathrm{C}\right)$ for 75 minutes, or solution annealed at $1150^{\circ} \mathrm{C}\left(\mathrm{SA} 1150^{\circ} \mathrm{C}\right)$ for 60 minutes. Specimens used for sodium exposure tests were fabricated from six lots of six different processing and heat treatment conditions listed in Table 2. Note that the thickness of the AOD plates was 1.2", and the thickness of the ESR and HOMO plates was 1.1".

Subsize sheet-type tensile specimens (Fig. 1 [1]) were electrical-discharge-machined with the gage parallel to the rolling direction. The design of extended grip sections of a subsized tensile specimen was to ensure that the microstructural characterization and the tensile test were carried out on a single sample exposed to the same sodium exposure condition. The tensile specimen has nominal gage dimensions of $7.62 \times 1.52 \times 0.76 \mathrm{~mm}$.

Table 1. Chemical composition of melt of A709 first commercial heat, H58776 (wt\%)

\begin{tabular}{|c|c|c|c|c|c|c|c|c|c|c|c|}
\hline Alloy 709 & $\mathrm{C}$ & $\mathrm{Cr}$ & $\mathrm{Ni}$ & $\mathrm{Mn}$ & $\mathrm{Mo}$ & $\mathrm{N}$ & $\mathrm{Si}$ & $\mathrm{P}$ & $\mathrm{Ti}$ & $\mathrm{Nb}$ & $\mathrm{B}$ \\
\hline Specifications & $\begin{array}{c}0.04- \\
0.10\end{array}$ & $\begin{array}{c}19.5- \\
23\end{array}$ & $23-26$ & 1.5 & $\begin{array}{c}1.0- \\
2.0\end{array}$ & $\begin{array}{c}0.14- \\
0.16\end{array}$ & 1.0 & $<0.025$ & 0.2 & $0.1-0.4$ & $0.002-0.01$ \\
\hline Aim & 0.07 & 20 & 25 & 0.9 & 1.5 & 0.15 & 0.40 & $*$ & 0.05 & 0.25 & $0.002-0.005$ \\
\hline Actual & 0.066 & 19.93 & 24.98 & 0.91 & 1.51 & 0.148 & 0.44 & 0.014 & 0.04 & 0.26 & 0.0045 \\
\hline
\end{tabular}

*The P shall not exceed 0.025 wt.\%.

Table 2. Processing-heat treatment conditions of A709 H58776 examined in this work.

\begin{tabular}{|l|c|c|c|}
\hline $\begin{array}{l}\text { Processing/heat } \\
\text { treatment ID }\end{array}$ & $\begin{array}{c}\text { Processing } \\
\text { condition }\end{array}$ & $\begin{array}{c}\text { Solution anneal (SA) } \\
\text { temperature }\left({ }^{\circ} \mathrm{C}\right)\end{array}$ & ANL Lot ID \\
\hline AOD-SA $1100^{\circ} \mathrm{C}$ & AOD & 1100 & $58776-4-\mathrm{B} 2$ \\
\hline AOD-SA $1150^{\circ} \mathrm{C}$ & AOD & 1150 & $58776-4-\mathrm{C} 2$ \\
\hline ESR-SA $1100^{\circ} \mathrm{C}$ & ESR & 1100 & $58776-3 R B-B 2$ \\
\hline ESR-SA $1150^{\circ} \mathrm{C}$ & ESR & 1150 & $58776-3 R B-C 2$ \\
\hline HOMO-SA $1100^{\circ} \mathrm{C}$ & ESR-Homo & 1100 & $58776-3 R A-B 2$ \\
\hline HOMO-SA $1150^{\circ} \mathrm{C}$ & ESR-Homo & 1150 & $58776-3 R A-C 2$ \\
\hline
\end{tabular}




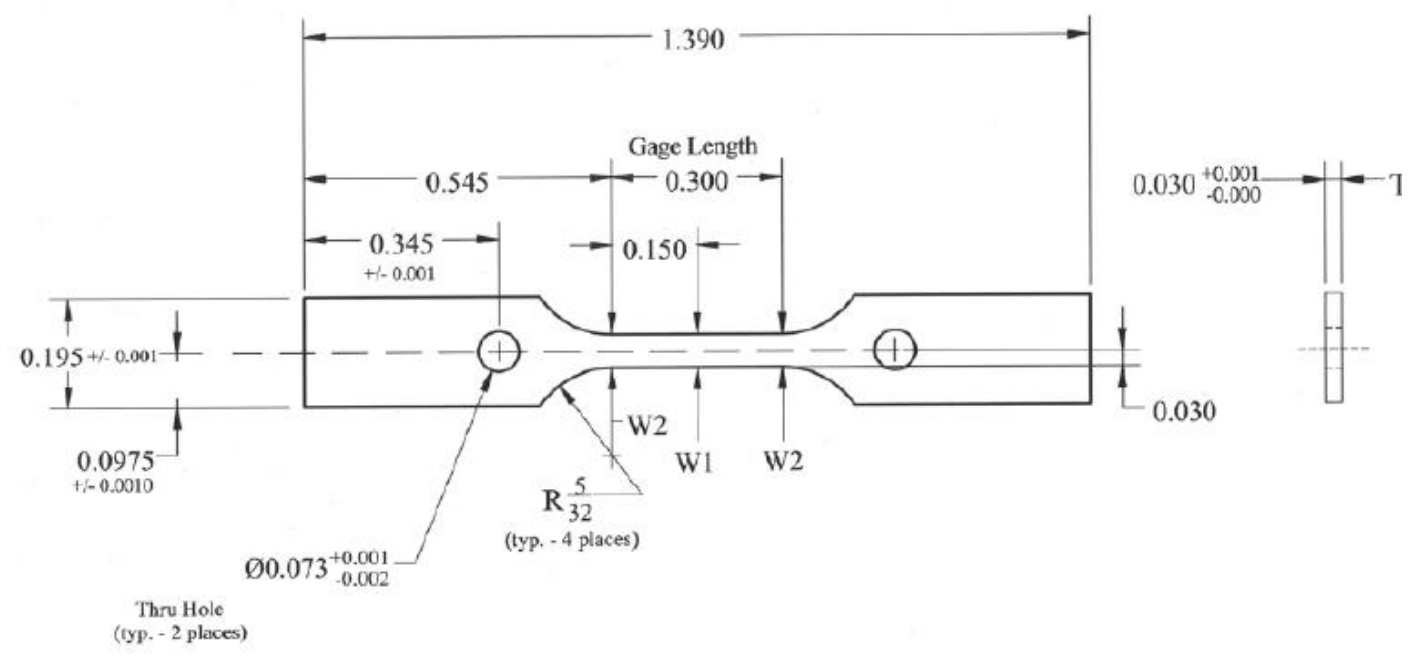

Figure 1. Schematic drawing of subsize sheet-type tensile specimens (unit: in).

\subsection{Forced convection sodium loops}

Two forced convection sodium materials testing loops were constructed for sodium exposure tests of advanced materials at the Argonne National Laboratory. The Sodium Materials Test Loop 1 (SMT-1) (shown in Fig. 2(a) [1]) consists of a single specimen exposure vessel, an electromagnetic pump, two electromagnetic flow meters, an economizer, and a cold trap. The total amount of sodium in the SMT-1 is approximately $10 \mathrm{~kg}$. The vessel has large penetrations at the top for sample loading as well as small penetrations for a level probe, a thermocouple, and an argon/vacuum line. The maximum operating pressure and temperature of the specimen vessel are 5 psig and $700^{\circ} \mathrm{C}$, respectively. The SMT-1 loop has been operating at $650^{\circ} \mathrm{C}$.

The Sodium Materials Test Loop 2 (SMT-2) (shown in Fig. 2(b) [2]) is a dual samplevessel loop for sodium exposures at two temperatures. The maximum operating pressure and temperature for the two sample vessels are $5 \mathrm{psig}$ and $700^{\circ} \mathrm{C}$, respectively. The total amount of sodium in the SMT-2 is approximately $20 \mathrm{~kg}$. The loop is equipped with electromagnetic pumps, electromagnetic flow meters, economizers, and a cold trap. Each vessel has two penetrations at the top for sample loading as well as smaller penetrations for a level probe, thermocouple, and argon/vacuum line. The SMT-2 loop has been operating at two temperatures, with one sample vessel at $550^{\circ} \mathrm{C}$, and the other at $600^{\circ} \mathrm{C}$.

Both loops are constructed of austenitic stainless steels. The oxygen content of the sodium is controlled by the cold trap in both loops. The temperature of the cold trap is maintained at $125^{\circ} \mathrm{C}$ to ensure that the oxygen concentration in sodium is at $\sim 1 \mathrm{wppm}$ during specimen exposure. 


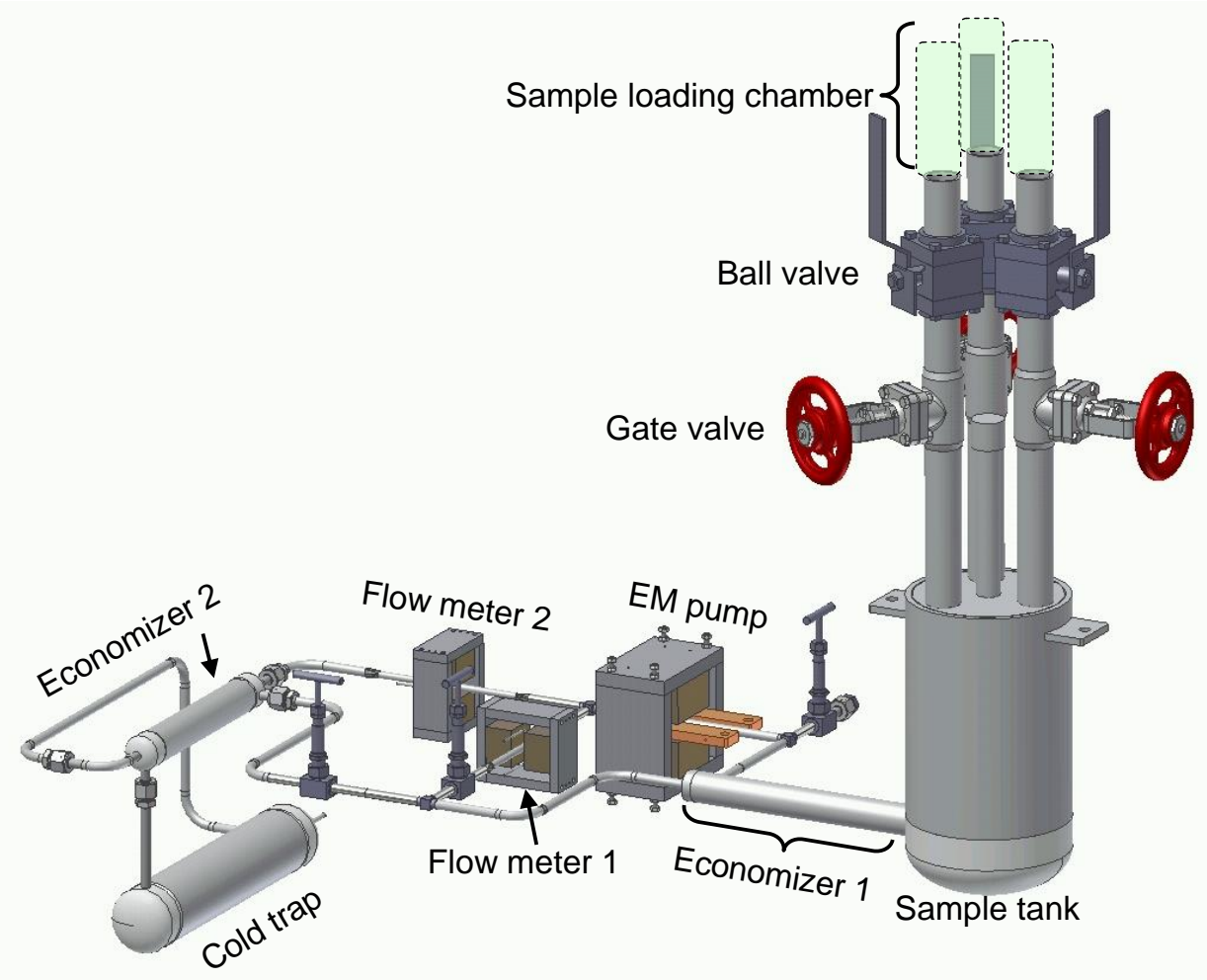

(a)

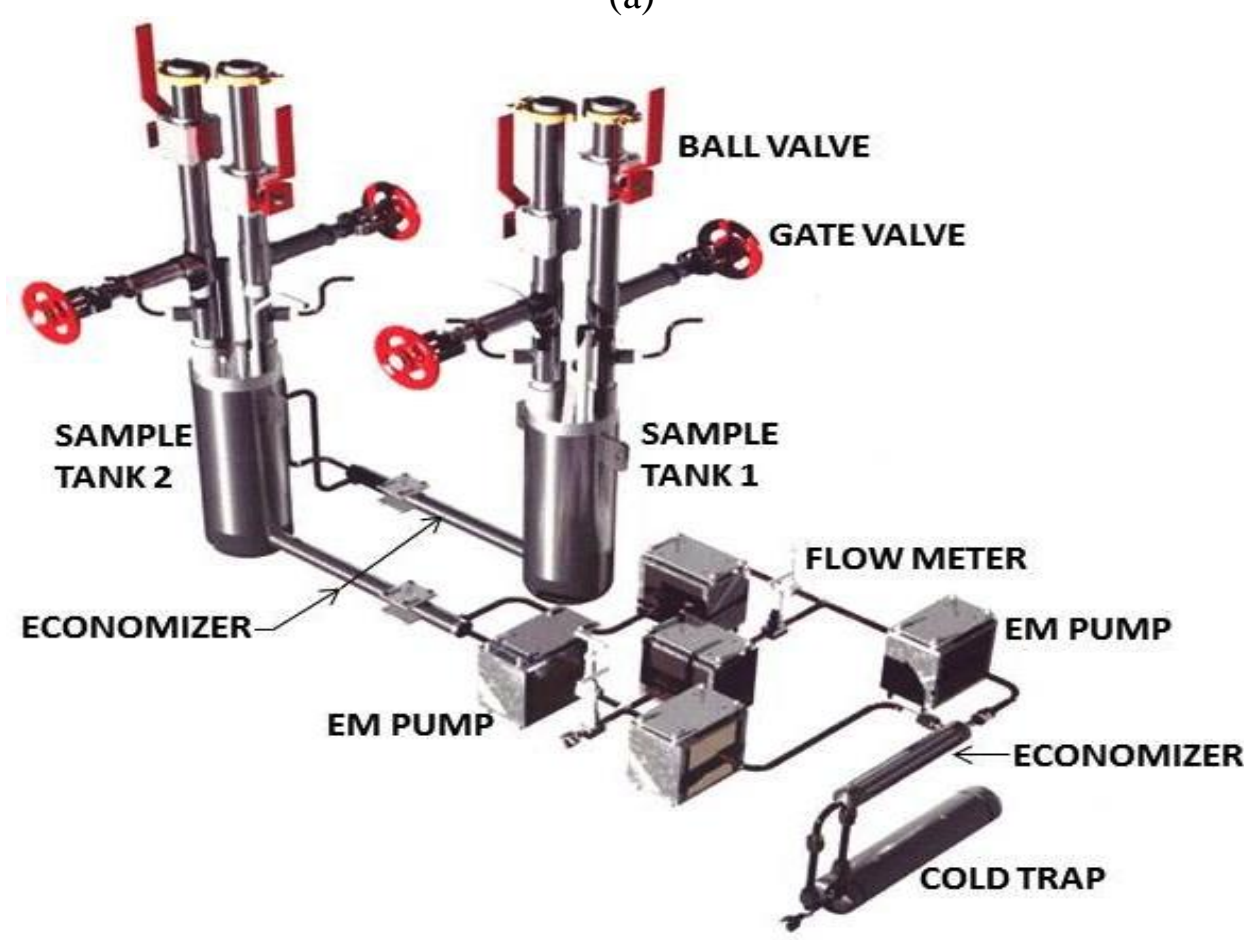

(b)

Figure 2. Isometric view of (a) the Sodium Materials Test Loop 1 (SMT-1) and (b) the Sodium Materials Test Loop 2 (SMT-2). 


\subsection{Sodium exposure tests}

Specimens in six different processing-heat treatment conditions of $\mathrm{H} 58776$ were tested at $650^{\circ} \mathrm{C}$ in sodium. Specimens in the AOD-SA $1100^{\circ} \mathrm{C}$ and AOD-SA $1150^{\circ} \mathrm{C}$ conditions were also tested at 550 and $600^{\circ} \mathrm{C}$. Prior to sodium exposure, each specimen was weighed three times using an OHAUS Model AP250 analytical balance to a precision of $10 \mu \mathrm{g}$. The thickness of the specimen was measured three times using a micrometer to a precision of $0.0001 \mathrm{in}$. After sodium exposure, the specimen was removed from the loop, cleaned with alcohol and then cleaned with water to remove sodium residues. Specimen surfaces were visually inspected and recorded by a digital camera if needed. Mass and thickness measurements were conducted to determine the mass and thickness changes resulted from sodium exposures. The post-exposure weight and thickness data were compared with the pre-exposure weight and thickness values to estimate the corrosion rates. If only non-destructive (weight and thickness) measurements were performed on a specimen, the specimen was reloaded into the sodium loops for a continued exposure.

Destructive examinations after sodium exposures include microstructural characterization and tensile tests. The extended grip sections of the exposed tensile specimen were cut from both ends before the tensile test for microstructural analysis. A metallographic specimen was prepared from the cross section for microstructural characterization by optical microscopy (OM), scanning electron microscopy (SEM), and micro-hardness measurements. Thin foil disk specimens of 3$\mathrm{mm}$ in diameter were made for microstructural characterization by transmission electron microscopy (TEM). TEM specimens were electropolished to perforation using a Tenupol twin-jet polishing unit.

Sodium-exposed sheet-type subsize tensile specimens were tested under uniaxial tension at the $\mathrm{Na}$ exposure temperature in an air furnace to examine the effect of sodium exposure on tensile properties. Tensile tests were performed in an electromechanical testing system equipped with a three-zone air furnace. The applied load was recorded by a load cell. The specimen displacement was measured by the crosshead extension. The engineering tensile properties were determined from the analysis of the load and displacement data. All the tests were conducted at a nominal strain rate, $0.001 \mathrm{~s}^{-1}$.

\subsection{Thermal aging tests}

Parallel thermal aging experiments were conducted to obtain thermal aging data for comparison with sodium exposure data to separate the thermal and sodium exposure effects. When a material is exposed to sodium at temperature, thermal aging will take place simultaneously. Thus sodium exposure data contain both sodium exposure and thermal aging effects. If design factors are developed directly from the sodium exposure data, the thermal aging contribution will be accounted for twice as thermal aging factors for yield and ultimate strengths are already implemented in the ASME Code, leading to unnecessary conservatism. In order to understand the direct effect of sodium on the tensile properties, two companion exposure testing programs, one for sodium exposure and the other for thermal aging, are being conducted.

Thermal aging experiments were performed in air furnaces using the same type of specimens shown in Fig. 1. Each specimen was wrapped in Ta foil and encapsulated in a quartz 
tube under vacuum. Encapsulated specimens were loaded in an air furnace that was heated to the target temperature for a desired period. Thermal aging experiments were conducted at $650^{\circ} \mathrm{C}$ on specimens of six different processing-heat treatment conditions of H58776. Specimens in the AOD-SA $1100^{\circ} \mathrm{C}$ and AOD-SA $1150^{\circ} \mathrm{C}$ conditions were also tested at 550 and $600^{\circ} \mathrm{C}$.

Microstructure of the thermally-aged specimens was characterized by optical microscopy (OM), scanning electron microscopy (SEM), transmission electron microscopy (TEM), and energy dispersive spectroscopy (EDS). Tensile tests were conducted under uniaxial tension at the aging temperature in an air furnace at a nominal strain rate of $0.001 / \mathrm{s}$.

\section{Results}

\subsection{Corrosion behavior of A709 H58776}

Figure 3 shows the corrosion data for the $650^{\circ} \mathrm{C}$ sodium exposure tests for $\mathrm{H} 58776$ of A709. The corrosion rate is plotted as a function of exposure time. The corrosion rate, $C R$ in $\mu \mathrm{m}$ per year $(\mu \mathrm{m} / \mathrm{y})$ was calculated from the weight change, $w$ using Eq. (1):

$$
C R=\frac{W}{\rho A t}
$$

where $\rho$ is the density $\left(7.8 \mathrm{~g} / \mathrm{cm}^{3}\right), A$ is the specimen surface area, and $t$ is the exposure time. The weight data given in Fig. 3 represent an average of three measurements for a specimen before and after sodium exposure. A709 H58776 specimens generally showed a weight loss after sodium exposures at $650^{\circ} \mathrm{C}$ except a few data points of the ESR-SA $1100^{\circ} \mathrm{C}$ specimens. The corrosion rates of both A709 and $316 \mathrm{H}$ stainless steels decreased with increasing exposure time. The corrosion rates showed large variations in the initial stage, likely due to selective corrosion resulted from dissolution of alloying elements. In the isothermal sodium condition, the corrosion slows down when the dissolved elements gradually reach saturation at the exposure temperature. Long-term exposure tests are needed to determine the steady-state corrosion rate of A709 steel. 


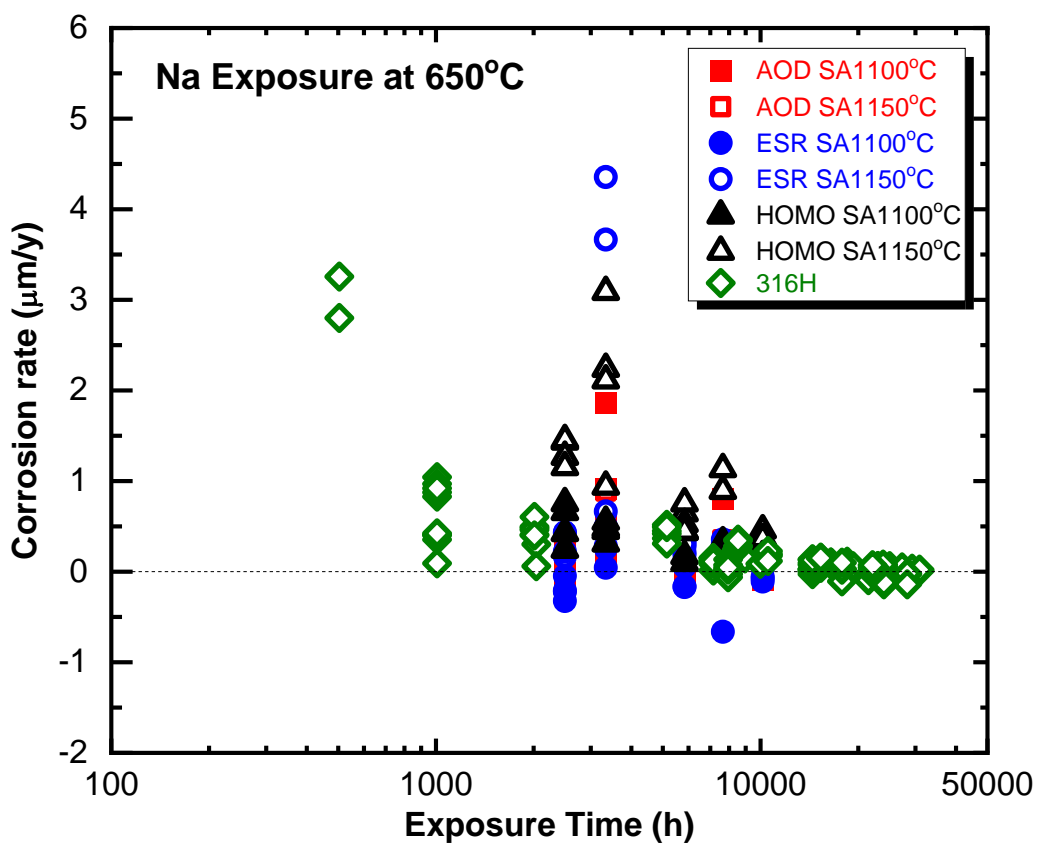

Figure 3. Corrosion rate as a function of $\mathrm{Na}$ exposure time at $650^{\circ} \mathrm{C}$ for $\mathrm{A} 709 \mathrm{H} 58776$ in six different processing-heat treatment conditions.

\subsection{Effect of sodium exposure on tensile properties of A709 H58776}

Table 3 summarizes the tensile properties, i.e. the yield stress (YS), ultimate tensile strength (UTS), uniform elongation (UE), and total elongation for A709 H58776 in six processingheat treatment conditions before exposure, after thermal aging at $650^{\circ} \mathrm{C}$, or after sodium exposure at $650^{\circ} \mathrm{C}$ for times of $\sim 3,000$ and $\sim 10,000 \mathrm{~h}$, respectively. All the tensile tests were conducted at the exposure temperature, $650^{\circ} \mathrm{C}$ in air.

Figure 4(a) shows the stress-strain curves of the AOD-SA $1100^{\circ} \mathrm{C}$ specimens before exposure, after thermal exposure at $650^{\circ} \mathrm{C}$ for $3,144 \mathrm{~h}$, and after sodium exposures at $650^{\circ} \mathrm{C}$ for $3,336 \mathrm{~h}$, respectively; Fig. 4(b) compares the stress-strain curves of the AOD-SA $1100^{\circ} \mathrm{C}$ specimens before exposure, after thermal exposure at $650^{\circ} \mathrm{C}$ for $10,056 \mathrm{~h}$, and after sodium exposures at $650^{\circ} \mathrm{C}$ for $10,152 \mathrm{~h}$, respectively. Thermal or sodium exposures at $650^{\circ} \mathrm{C}$ increased the yield stress, decreased the ultimate tensile strength, and reduced uniform and total elongations. The sodium-exposed specimens had a higher tensile strength than the thermally-aged specimens. A longer exposure time (10kh vs. $3 \mathrm{kh}$ ) had a minimal effect on the tensile strength but further reduced the tensile ductility of the AOD-SA $1100^{\circ} \mathrm{C}$ specimen.

Figure 5(a) shows the stress-strain curves of the ESR-SA $1100^{\circ} \mathrm{C}$ specimens before exposure, after thermal exposure at $650^{\circ} \mathrm{C}$ for $3,144 \mathrm{~h}$, and after sodium exposures at $650^{\circ} \mathrm{C}$ for 3,336 h, respectively; Fig. 5(b) compares the stress-strain curves of the ESR-SA $1100^{\circ} \mathrm{C}$ specimens before exposure, after thermal exposure at $650^{\circ} \mathrm{C}$ for $10,056 \mathrm{~h}$, and after sodium exposures at $650^{\circ} \mathrm{C}$ for $10,152 \mathrm{~h}$, respectively. At an exposure time of $\sim 3,000 \mathrm{~h}$, thermal or sodium exposures reduced the tensile strength and uniform and total elongations of the ESR-SA $1100^{\circ} \mathrm{C}$ specimens, 
similar to the AOD-SA $1100^{\circ} \mathrm{C}$ specimens. However, at an exposure time of $\sim 10,000 \mathrm{~h}$ thermal or sodium exposures increased the yield stress and the ultimate tensile strength. All the sodiumexposed specimens had higher tensile strength than the thermally-aged specimens in the ESR$\mathrm{SA} 1100^{\circ} \mathrm{C}$ condition.

Figure 6(a) shows the stress-strain curves of the HOMO-SA $1100^{\circ} \mathrm{C}$ specimens before exposure, after thermal exposure at $650^{\circ} \mathrm{C}$ for $3,144 \mathrm{~h}$, and after sodium exposures at $650^{\circ} \mathrm{C}$ for 3,336 h, respectively; Fig. 6(b) compares the stress-strain curves of the HOMO-SA $1100^{\circ} \mathrm{C}$ specimens before exposure, after thermal exposure at $650^{\circ} \mathrm{C}$ for $10,056 \mathrm{~h}$, and after sodium exposures at $650^{\circ} \mathrm{C}$ for $10,152 \mathrm{~h}$, respectively. Similar to the AOD-SA $1100^{\circ} \mathrm{C}$ specimens, thermal or sodium exposures at $650^{\circ} \mathrm{C}$ increased the yield stress, decreased the ultimate tensile strength, and reduced uniform and total elongations of the HOMO-SA $1100^{\circ} \mathrm{C}$ specimens. The sodiumexposed specimens had somewhat higher yield stress and ultimate tensile strength than the thermally-aged specimens. A longer exposure time (10kh vs. $3 \mathrm{kh}$ ) had a minimal effect on the strength but further reduced the ductility of the $\mathrm{HOMO}-\mathrm{SA} 1100^{\circ} \mathrm{C}$ specimen.

Figure 7(a) shows the stress-strain curves of the AOD-SA $1150^{\circ} \mathrm{C}$ specimens before exposure, after thermal exposure at $650^{\circ} \mathrm{C}$ for $3,144 \mathrm{~h}$, and after sodium exposures at $650^{\circ} \mathrm{C}$ for $3,336 \mathrm{~h}$, respectively; Fig. 7(b) compares the stress-strain curves of the AOD-SA $1150^{\circ} \mathrm{C}$ specimens before exposure, after thermal exposure at $650^{\circ} \mathrm{C}$ for $10,056 \mathrm{~h}$, and after sodium exposures at $650^{\circ} \mathrm{C}$ for $10,152 \mathrm{~h}$, respectively. Thermal or sodium exposures at $650^{\circ} \mathrm{C}$ again increased the yield stress, decreased the ultimate tensile strength, and reduced uniform and total elongations. There were minimal differences in tensile properties between the sodium-exposed and thermally-aged specimens after a $\sim 3000 \mathrm{~h}$ exposure. However, the sodium-exposed specimens showed higher yield stress and ultimate tensile strength and lower uniform and total elongations than the thermally-aged specimens after exposure for $\sim 10,000 \mathrm{~h}$.

Figure 8 (a) shows the stress-strain curves of the ESR-SA $1150^{\circ} \mathrm{C}$ specimens before exposure, after thermal exposure at $650^{\circ} \mathrm{C}$ for $3,144 \mathrm{~h}$, and after sodium exposures at $650^{\circ} \mathrm{C}$ for 3,336 h, respectively; Fig. 8(b) compares the stress-strain curves of the ESR-SA $1150^{\circ} \mathrm{C}$ specimens before exposure, after thermal exposure at $650^{\circ} \mathrm{C}$ for $10,056 \mathrm{~h}$, and after sodium exposures at $650^{\circ} \mathrm{C}$ for $10,152 \mathrm{~h}$, respectively. Similar to the AOD-SA $1150^{\circ} \mathrm{C}$ specimens, thermal or sodium exposures at $650^{\circ} \mathrm{C}$ increased the yield stress, decreased the ultimate tensile strength, and reduced uniform and total elongations of the ESR-SA $1150^{\circ} \mathrm{C}$ specimens. There were minimal differences in tensile properties between the sodium-exposed and thermally-aged specimens after an $\sim 3000 \mathrm{~h}$ exposure. However, the sodium-exposed specimens showed higher yield stress and ultimate tensile strength and lower uniform and total elongations than the thermally-aged specimens after exposure for $\sim 10,000 \mathrm{~h}$.

Figure 9(a) shows the stress-strain curves of the HOMO-SA $1150^{\circ} \mathrm{C}$ specimens before exposure, after thermal exposure at $650^{\circ} \mathrm{C}$ for $3,144 \mathrm{~h}$, and after sodium exposures at $650^{\circ} \mathrm{C}$ for 3,336 h, respectively; Fig. 9(b) compares the stress-strain curves of the HOMO-SA $1150^{\circ} \mathrm{C}$ specimens before exposure, after thermal exposure at $650^{\circ} \mathrm{C}$ for $10,056 \mathrm{~h}$, and after sodium exposures at $650^{\circ} \mathrm{C}$ for $10,152 \mathrm{~h}$, respectively. Thermal or sodium exposures at $650^{\circ} \mathrm{C}$ significantly increased the yield stress but had a minimal effect on the ultimate tensile strength. Both uniform and total elongations were significantly reduced after thermal or sodium exposures even for only 
$\sim 3,000 \mathrm{~h}$, and both uniform and total elongations were further reduced after an exposure of $\sim 10,000$ $\mathrm{h}$. The sodium-exposed specimens had lower tensile ductility than the thermally-aged specimens.

All the stress-strain curves of A709 H58776 in the as-received condition showed pronounced serrations of the plastic flow curves due to the dynamic strain aging effect. Serrations of the flow curves were visible up to the maximum load ( $48 \%$ strain) for the $\mathrm{HOMO}-\mathrm{SA} 1150^{\circ} \mathrm{C}$ specimen, while serrations disappeared at a strain of $17 \%$ in the ESR-SA $1100^{\circ} \mathrm{C}$ specimen. Serrations vanished at strains of $26 \%, 30 \%, 31 \%$, and $36 \%$ in the specimens of $\mathrm{HOMO}-\mathrm{SA} 1100^{\circ} \mathrm{C}$, ESR-SA $1150^{\circ} \mathrm{C}$, AOD-SA $1100^{\circ} \mathrm{C}$, and AOD-SA $1150^{\circ} \mathrm{C}$, respectively. Thermal aging or sodium exposures at $650^{\circ} \mathrm{C}$ after $\sim 10,000 \mathrm{~h}$ completely removed the serrations of the flow curves in H58776. Dynamic strain aging is an interaction between free interstitials (e.g. carbon, nitrogen) and dislocations. Because of the high mobility of interstitial atoms, they segregate to the dislocations, and cause repeated locking and unlocking of dislocations during plastic flow, resulting in the serrated flow. The elimination of serrations of the flow curves in A709 H58776 after aging or sodium exposure imply that carbon or nitrogen in solution available for strain aging was removed from the solution and form precipitates during aging or sodium exposures.

Figure 10 compares the tensile properties of the three different processing conditions, AOD, ESR, and ESR-Homo in the $1100^{\circ} \mathrm{C}$-solution-annealed condition. Comparison of the tensile properties of the three different processing conditions, AOD, ESR, ESR-Homo in the $1150^{\circ} \mathrm{C}$ solution-annealed condition is given in Fig. 11. 
Table 3. Tensile properties of A709 H58776 after sodium or thermal exposures at $650^{\circ} \mathrm{C}$.

\begin{tabular}{|c|c|c|c|c|c|c|c|c|}
\hline $\begin{array}{l}\text { Processing/Heat } \\
\text { Treatment }\end{array}$ & $\begin{array}{l}\text { Exposure } \\
\text { Cond. }\end{array}$ & $\begin{array}{l}\text { Exposure } \\
\mathrm{T}\left({ }^{\circ} \mathrm{C}\right)\end{array}$ & $\begin{array}{l}\text { Exposure } \\
\text { time (h) }\end{array}$ & $\begin{array}{l}\text { Test T } \\
\left({ }^{\circ} \mathrm{C}\right)\end{array}$ & $\begin{array}{l}\text { YS } \\
(\mathrm{MPa})\end{array}$ & $\begin{array}{l}\text { UTS } \\
\text { (MPa) }\end{array}$ & $\begin{array}{l}\mathrm{UE} \\
(\%)\end{array}$ & $\begin{array}{l}\mathrm{TE} \\
(\%)\end{array}$ \\
\hline $\mathrm{AOD}$ SA $1100^{\circ} \mathrm{C}$ & $\mathrm{AR}$ & - & - & 650 & 191 & 501 & 39.2 & 49.1 \\
\hline AOD SA $1100^{\circ} \mathrm{C}$ & Aged & 650 & 3,144 & 650 & 226 & 435 & 20.1 & 39.0 \\
\hline $\mathrm{AOD}$ SA $1100^{\circ} \mathrm{C}$ & Aged & 650 & 10,056 & 650 & 274 & 433 & 19.0 & 37.3 \\
\hline AOD SA $1100^{\circ} \mathrm{C}$ & $\mathrm{Na}$ & 650 & 3,336 & 650 & 243 & 458 & 20.8 & 39.9 \\
\hline $\mathrm{AOD} \mathrm{SA} 1100^{\circ} \mathrm{C}$ & $\mathrm{Na}$ & 650 & 10,152 & 650 & 259 & 459 & 16.9 & 31.7 \\
\hline AOD SA $1150^{\circ} \mathrm{C}$ & $\mathrm{AR}$ & - & - & 650 & 186 & 501 & 41.2 & 50.1 \\
\hline AOD SA $1150^{\circ} \mathrm{C}$ & Aged & 650 & 3,144 & 650 & 219 & 444 & 20.4 & 37.5 \\
\hline $\mathrm{AOD} S A 1150^{\circ} \mathrm{C}$ & Aged & 650 & 10,056 & 650 & 225 & 430 & 18.5 & 36.7 \\
\hline AOD SA $1150^{\circ} \mathrm{C}$ & $\mathrm{Na}$ & 650 & 3,336 & 650 & 240 & 448 & 20.4 & 39.6 \\
\hline $\mathrm{AOD} \mathrm{SA} 1150^{\circ} \mathrm{C}$ & $\mathrm{Na}$ & 650 & 10,152 & 650 & 258 & 460 & 17.4 & 32.8 \\
\hline ESR SA $1100^{\circ} \mathrm{C}$ & $\mathrm{AR}$ & - & - & 650 & 232 & 509 & 32.2 & 47.2 \\
\hline ESR SA $1100^{\circ} \mathrm{C}$ & Aged & 650 & 3,144 & 650 & 218 & 446 & 21.2 & 39.7 \\
\hline ESR SA $1100^{\circ} \mathrm{C}$ & Aged & 650 & 10,056 & 650 & 250 & 527 & 20.2 & 40.0 \\
\hline ESR SA $1100^{\circ} \mathrm{C}$ & $\mathrm{Na}$ & 650 & 3,336 & 650 & 258 & 459 & 18.3 & 41.9 \\
\hline ESR SA $1100^{\circ} \mathrm{C}$ & $\mathrm{Na}$ & 650 & 10,152 & 650 & 280 & 548 & 18.7 & 37.0 \\
\hline ESR SA $1150^{\circ} \mathrm{C}$ & AR & - & - & 650 & 200 & 522 & 38.3 & 49.7 \\
\hline ESR SA $1150^{\circ} \mathrm{C}$ & Aged & 650 & 3,144 & 650 & 206 & 460 & 22.5 & 39.7 \\
\hline ESR SA $1150^{\circ} \mathrm{C}$ & Aged & 650 & 10,056 & 650 & 195 & 434 & 20.5 & 38.6 \\
\hline $\mathrm{ESR} S \mathrm{SA} 1150^{\circ} \mathrm{C}$ & $\mathrm{Na}$ & 650 & 3,336 & 650 & 245 & 455 & 21.5 & 35.0 \\
\hline ESR SA $1150^{\circ} \mathrm{C}$ & $\mathrm{Na}$ & 650 & 10,152 & 650 & 211 & 456 & 20.0 & 34.1 \\
\hline $\mathrm{HOMO} \mathrm{SA} 1100^{\circ} \mathrm{C}$ & $\mathrm{AR}$ & - & - & 650 & 205 & 506 & 35.9 & 48.8 \\
\hline $\mathrm{HOMO}$ SA $1100^{\circ} \mathrm{C}$ & Aged & 650 & 3,144 & 650 & 199 & 442 & 23.2 & 40.5 \\
\hline $\mathrm{HOMO} \mathrm{SA} 1100^{\circ} \mathrm{C}$ & Aged & 650 & 10,056 & 650 & 198 & 425 & 20.7 & 44.0 \\
\hline $\mathrm{HOMO}$ SA $1100^{\circ} \mathrm{C}$ & $\mathrm{Na}$ & 650 & 3,336 & 650 & 259 & 455 & 19.3 & 36.7 \\
\hline $\mathrm{HOMO}$ SA $1100^{\circ} \mathrm{C}$ & $\mathrm{Na}$ & 650 & 10,152 & 650 & 211 & 456 & 20.3 & 35.2 \\
\hline $\mathrm{HOMO}$ SA $1150^{\circ} \mathrm{C}$ & $\mathrm{AR}$ & - & - & 650 & 141 & 434 & 47.8 & 52.7 \\
\hline $\mathrm{HOMO}$ SA $1150^{\circ} \mathrm{C}$ & Aged & 650 & 3,144 & 650 & 191 & 449 & 26.2 & 42.8 \\
\hline $\mathrm{HOMO}$ SA $1150^{\circ} \mathrm{C}$ & Aged & 650 & 10,056 & 650 & 181 & 438 & 22.3 & 38.3 \\
\hline $\mathrm{HOMO}$ SA $1150^{\circ} \mathrm{C}$ & $\mathrm{Na}$ & 650 & 3,336 & 650 & 212 & 420 & 24.5 & 31.6 \\
\hline $\mathrm{HOMO}$ SA $1150^{\circ} \mathrm{C}$ & $\mathrm{Na}$ & 650 & 10,152 & 650 & 208 & 419 & 17.3 & 22.2 \\
\hline $\mathrm{HOMO}$ SA $1150^{\circ} \mathrm{C}$ & $\mathrm{Na}$ & 650 & 10,152 & 650 & 219 & 419 & 16.1 & 21.1 \\
\hline
\end{tabular}

Note: AR - as-received 


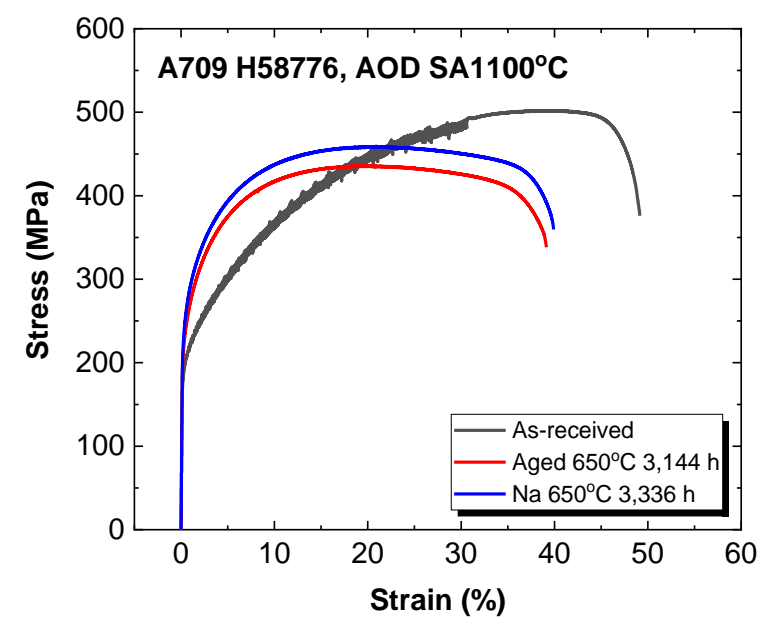

(a)

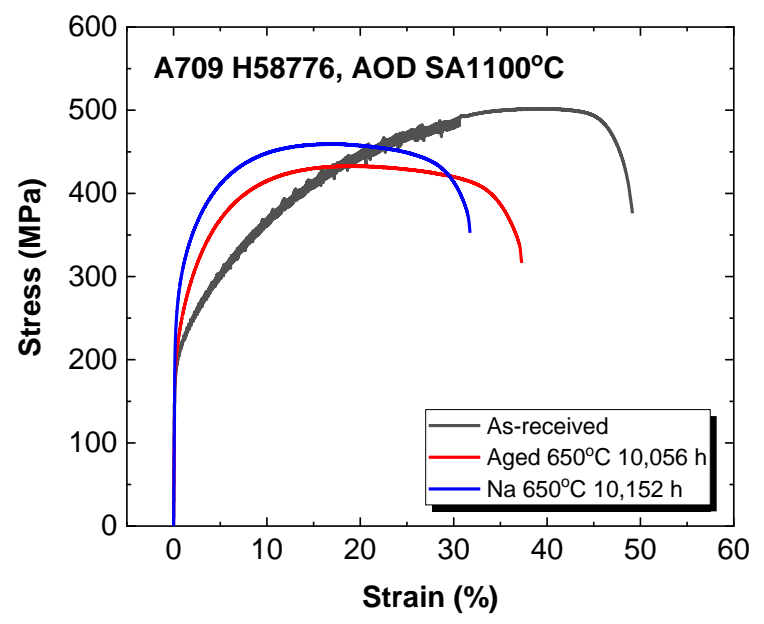

(b)

Figure 4. Stress-strain curves for the AOD-SA $1100^{\circ} \mathrm{C}$ specimens (a) before exposure, after thermal exposure at $650^{\circ} \mathrm{C}$ for $3,144 \mathrm{~h}$, and after sodium exposures at $650^{\circ} \mathrm{C}$ for $3,336 \mathrm{~h}$; (b) before exposure, after thermal exposure at $650^{\circ} \mathrm{C}$ for $10,056 \mathrm{~h}$, and after sodium exposures at $650^{\circ} \mathrm{C}$ for $10,152 \mathrm{~h}$.

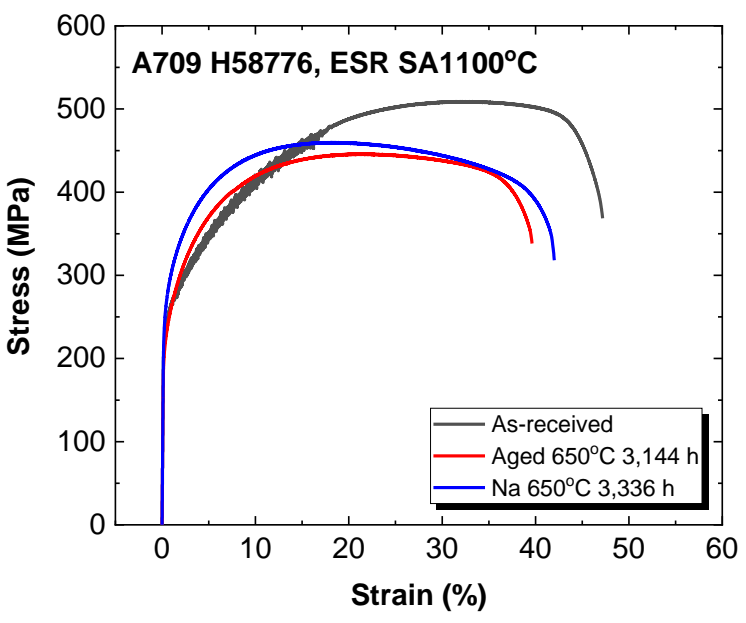

(a)

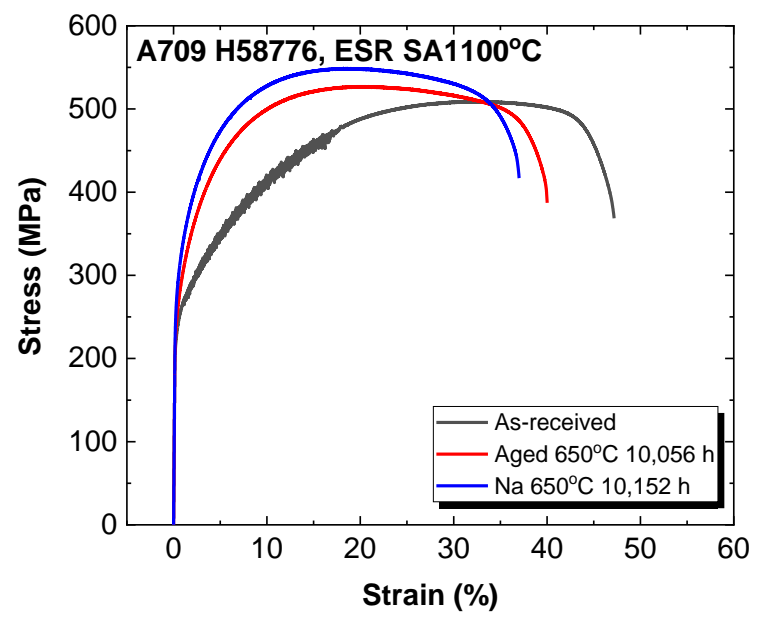

(b)

Figure 5. Stress-strain curves for the ESR-SA $1100^{\circ} \mathrm{C}$ specimens (a) before exposure, after thermal exposure at $650^{\circ} \mathrm{C}$ for $3,144 \mathrm{~h}$, and after sodium exposures at $650^{\circ} \mathrm{C}$ for $3,336 \mathrm{~h}$; (b) before exposure, after thermal exposure at $650^{\circ} \mathrm{C}$ for $10,056 \mathrm{~h}$, and after sodium exposures at $650^{\circ} \mathrm{C}$ for $10,152 \mathrm{~h}$. 


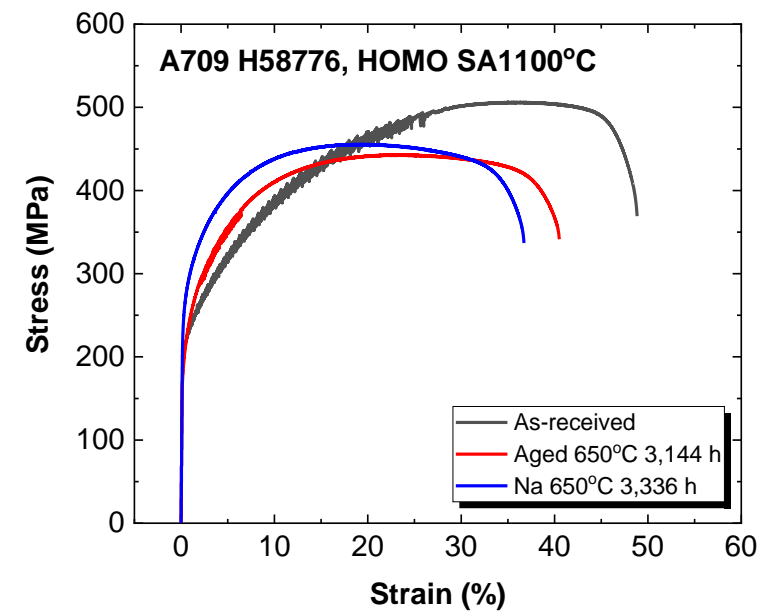

(a)

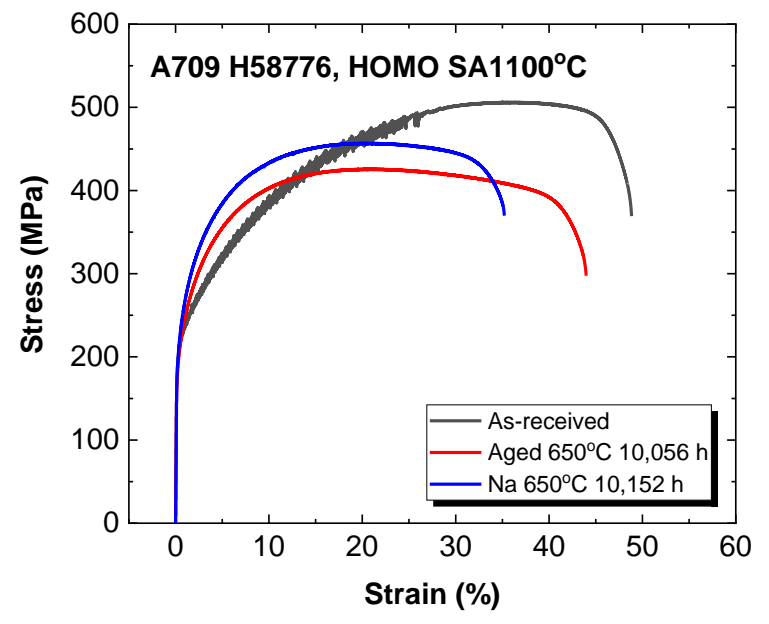

(b)

Figure 6. Stress-strain curves for the $\mathrm{HOMO}-\mathrm{SA} 1100^{\circ} \mathrm{C}$ specimens (a) before exposure, after thermal exposure at $650^{\circ} \mathrm{C}$ for $3,144 \mathrm{~h}$, and after sodium exposures at $650^{\circ} \mathrm{C}$ for $3,336 \mathrm{~h}$; (b) before exposure, after thermal exposure at $650^{\circ} \mathrm{C}$ for $10,056 \mathrm{~h}$, and after sodium exposures at $650^{\circ} \mathrm{C}$ for $10,152 \mathrm{~h}$.

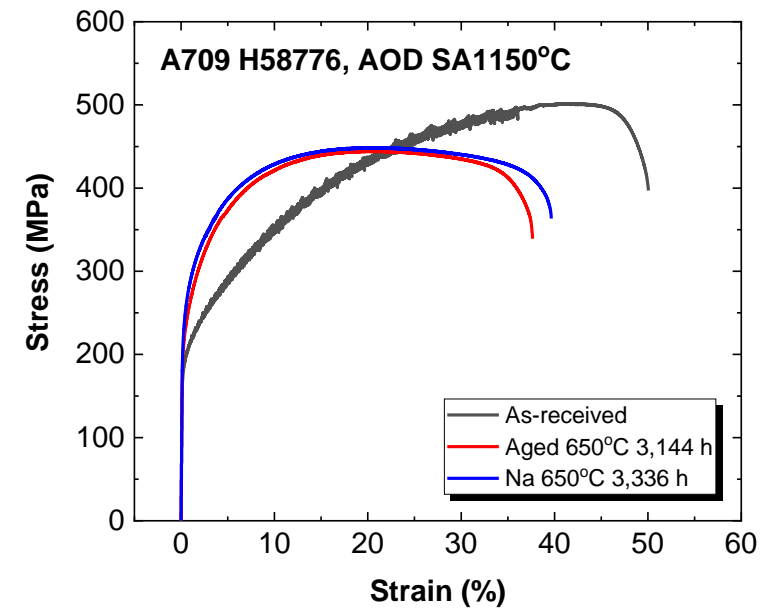

(a)

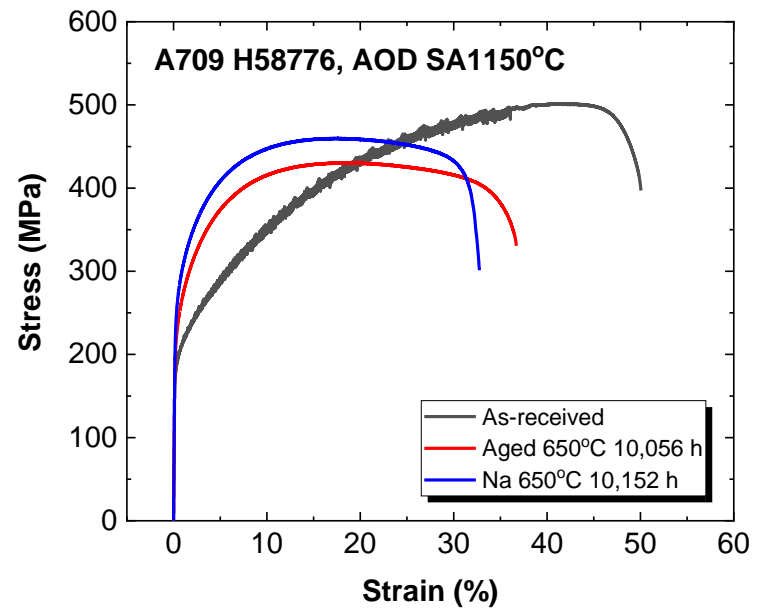

(b)

Figure 7. Stress-strain curves for the AOD-SA $1150^{\circ} \mathrm{C}$ specimens (a) before exposure, after thermal exposure at $650^{\circ} \mathrm{C}$ for $3,144 \mathrm{~h}$, and after sodium exposures at $650^{\circ} \mathrm{C}$ for $3,336 \mathrm{~h}$; (b) before exposure, after thermal exposure at $650^{\circ} \mathrm{C}$ for $10,056 \mathrm{~h}$, and after sodium exposures at $650^{\circ} \mathrm{C}$ for $10,152 \mathrm{~h}$. 


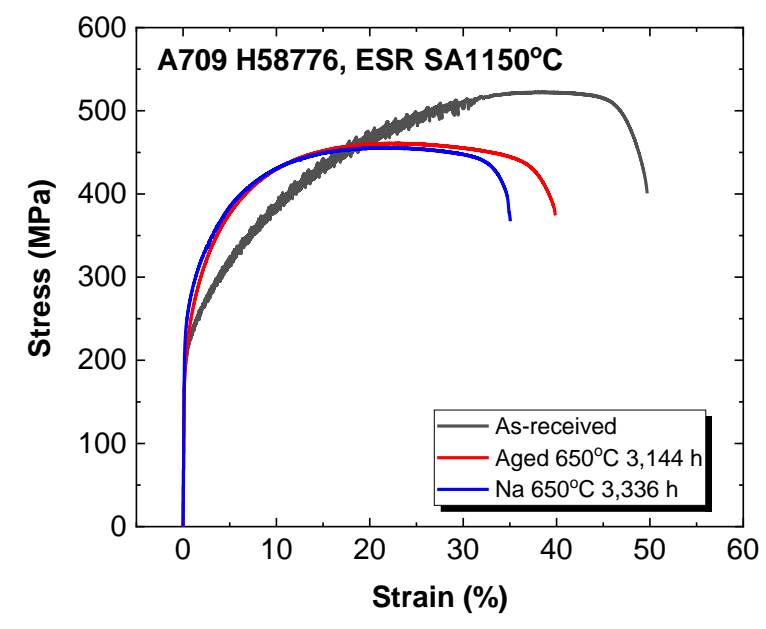

(a)

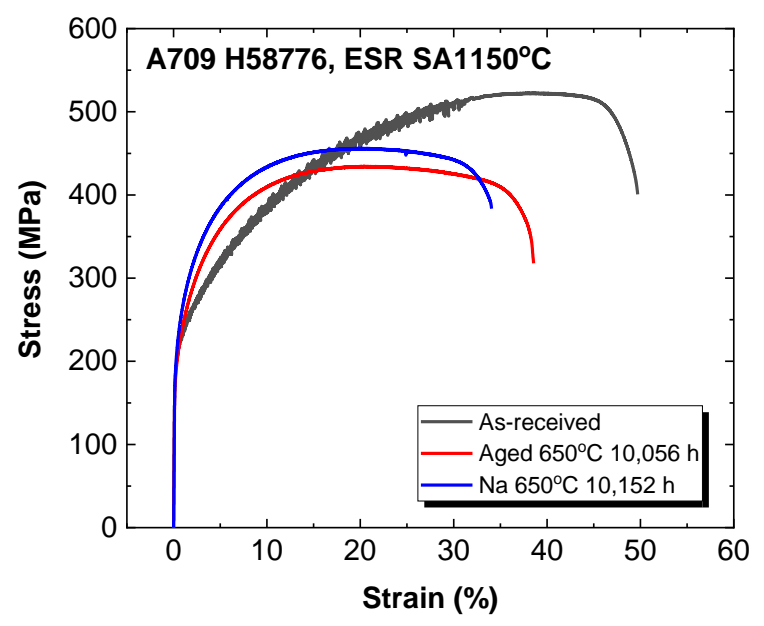

(b)

Figure 8. Stress-strain curves for the ESR-SA $1150^{\circ} \mathrm{C}$ specimens (a) before exposure, after thermal exposure at $650^{\circ} \mathrm{C}$ for $3,144 \mathrm{~h}$, and after sodium exposures at $650^{\circ} \mathrm{C}$ for $3,336 \mathrm{~h}$; (b) before exposure, after thermal exposure at $650^{\circ} \mathrm{C}$ for $10,056 \mathrm{~h}$, and after sodium exposures at $650^{\circ} \mathrm{C}$ for $10,152 \mathrm{~h}$.

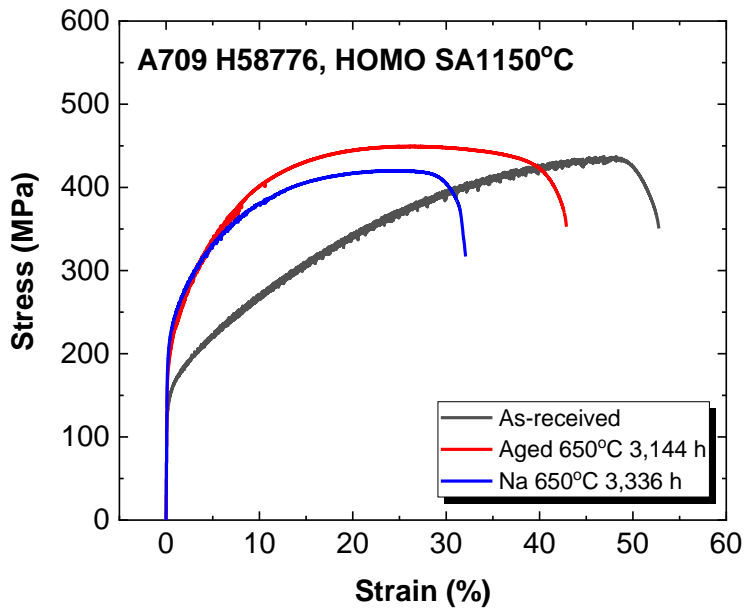

(a)

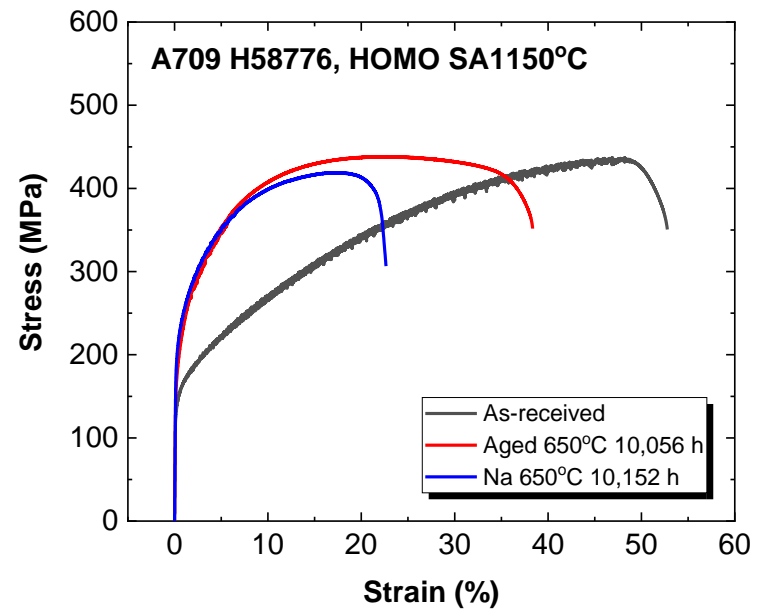

(b)

Figure 9. Stress-strain curves for the HOMO-SA $1150^{\circ} \mathrm{C}$ specimens (a) before exposure, after thermal exposure at $650^{\circ} \mathrm{C}$ for $3,144 \mathrm{~h}$, and after sodium exposures at $650^{\circ} \mathrm{C}$ for $3,336 \mathrm{~h}$; (b) before exposure, after thermal exposure at $650^{\circ} \mathrm{C}$ for $10,056 \mathrm{~h}$, and after sodium exposures at $650^{\circ} \mathrm{C}$ for $10,152 \mathrm{~h}$. 


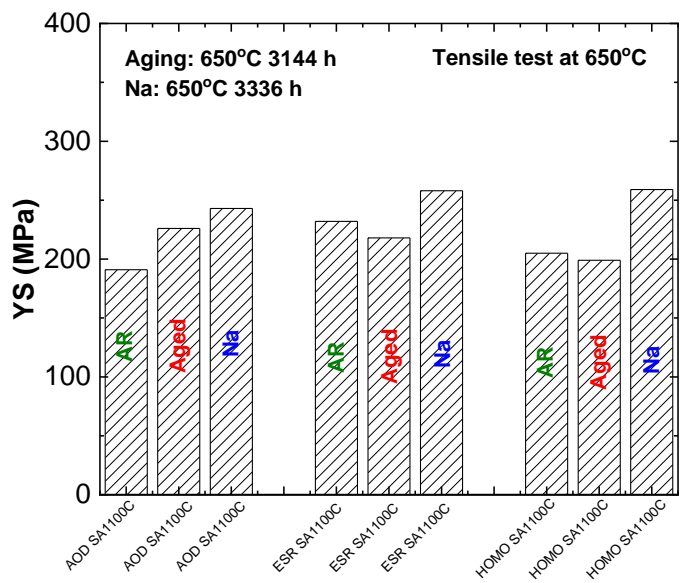

(a)

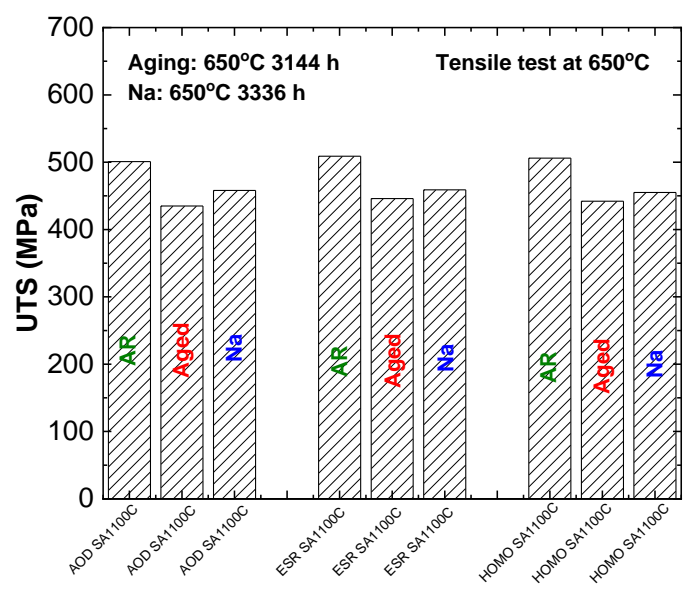

(c)

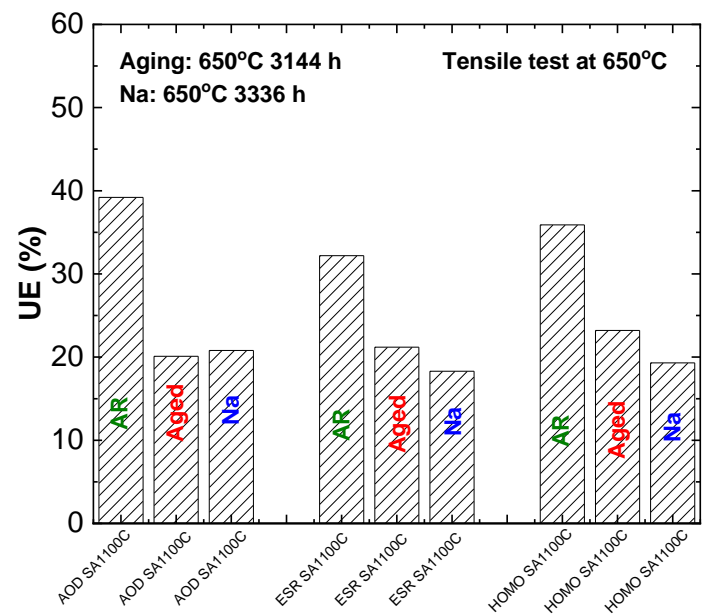

(e)

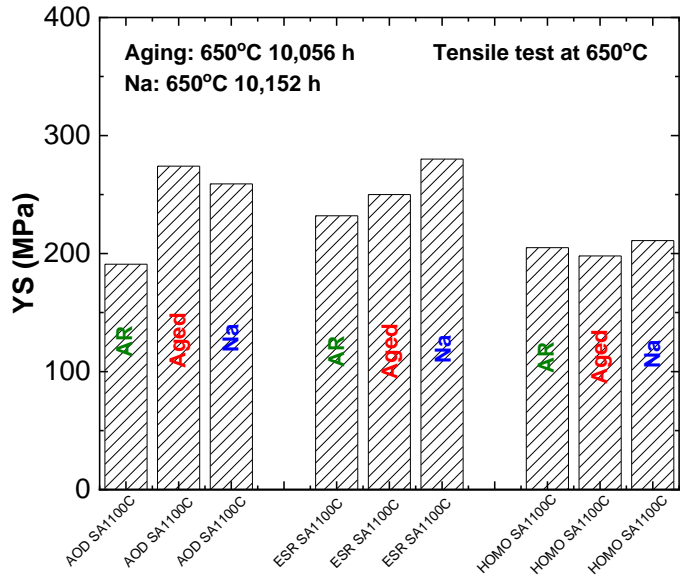

(b)

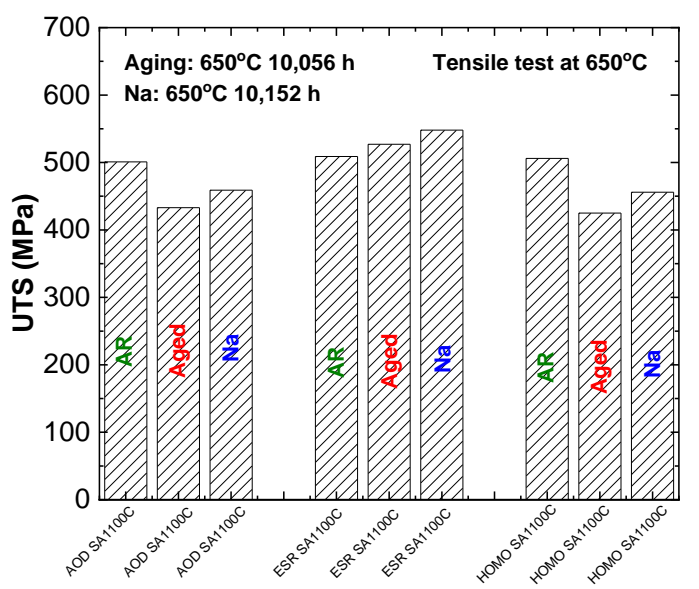

(d)

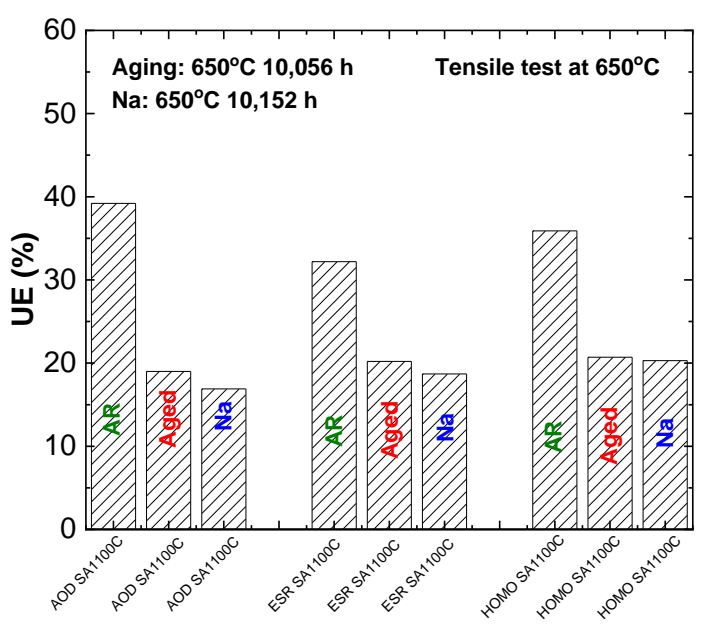

(f) 


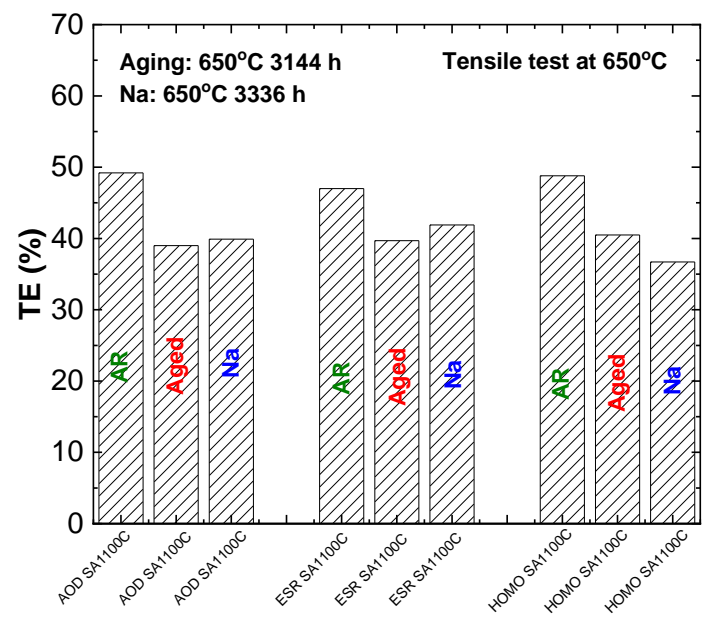

(g)

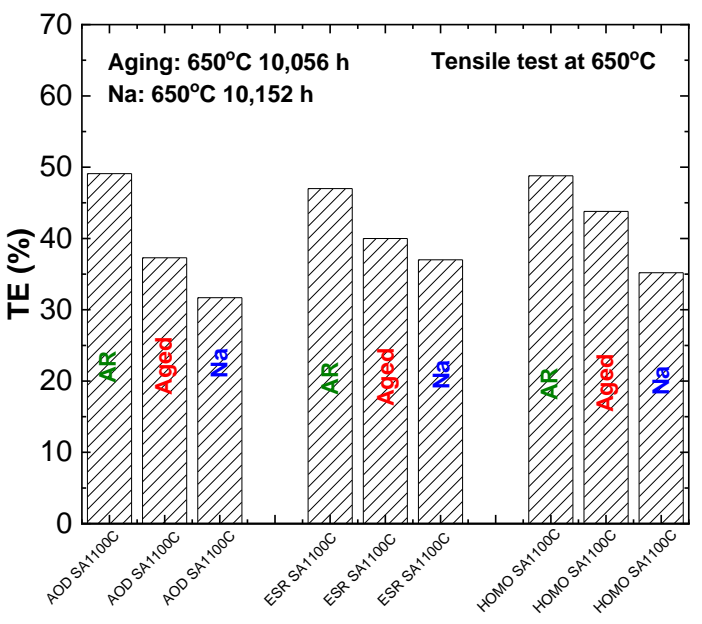

(h)

Figure 10. Comparison of yield stress, ultimate tensile strength, uniform elongation and total elongation for $1100^{\circ} \mathrm{C}$-solution-annealled A709 $\mathrm{H} 58776$.

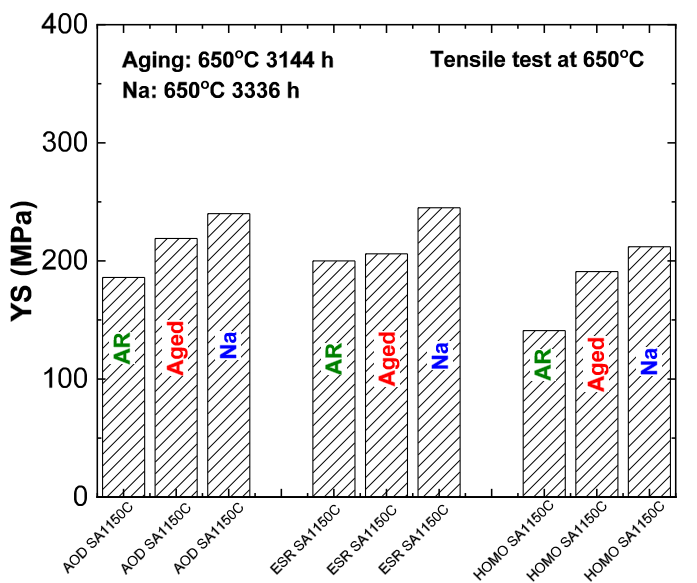

(a)

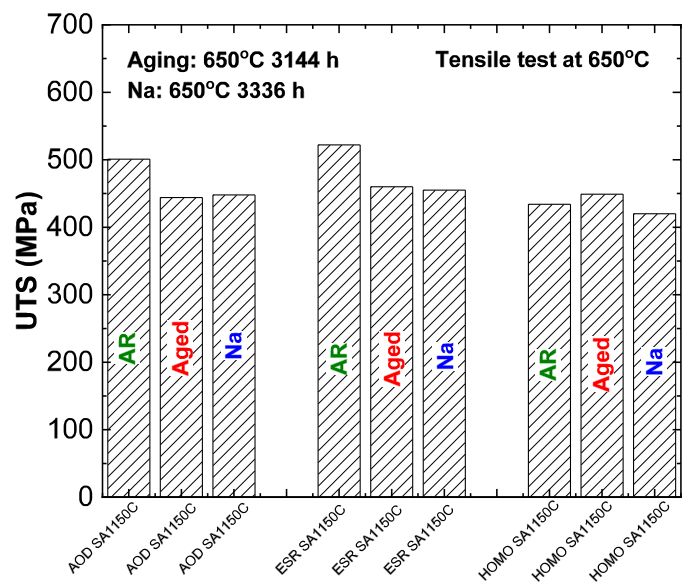

(c)

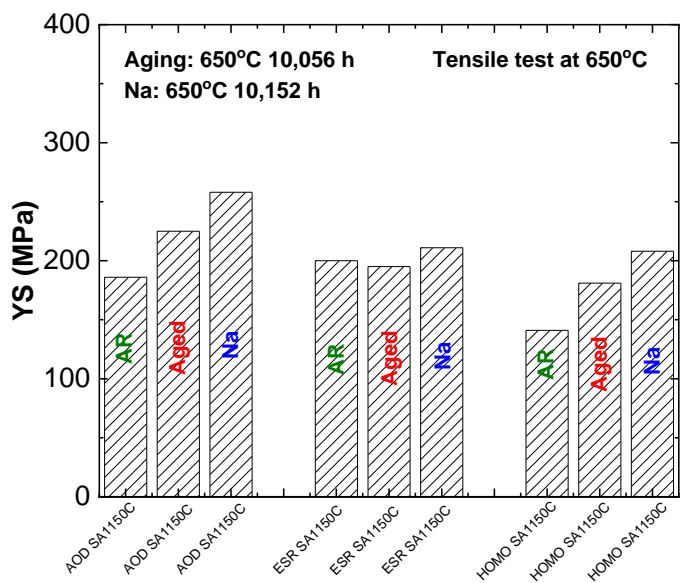

(b)

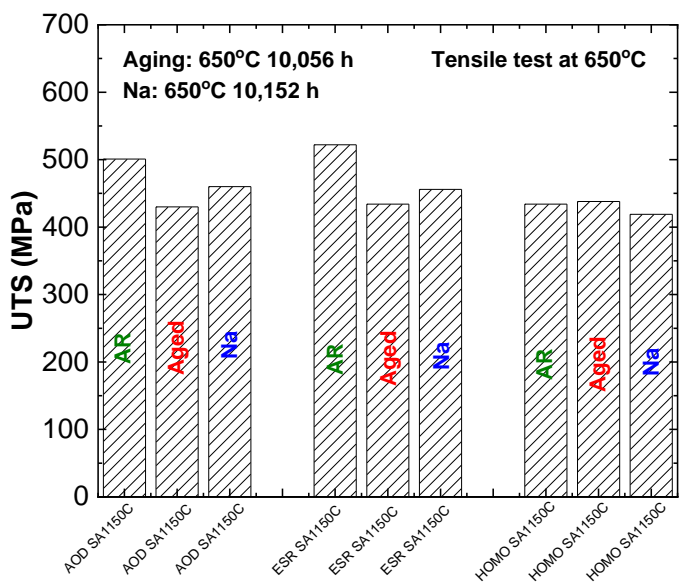

(d) 


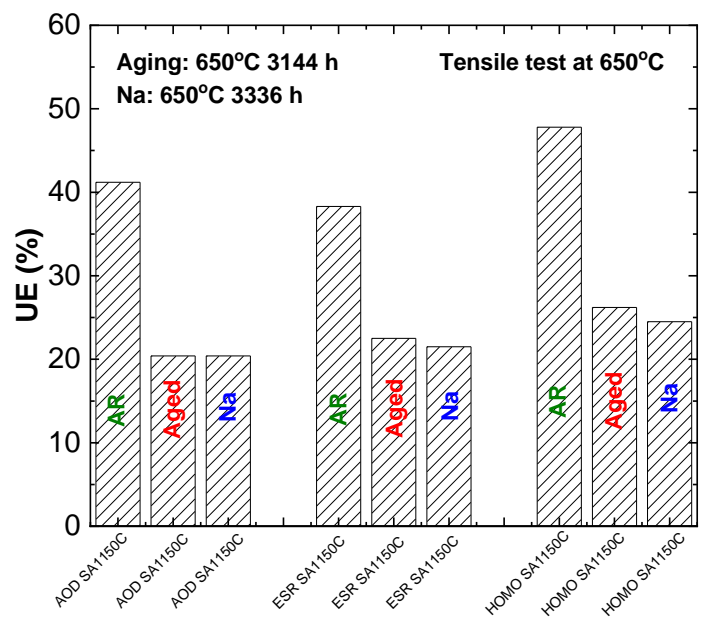

(e)

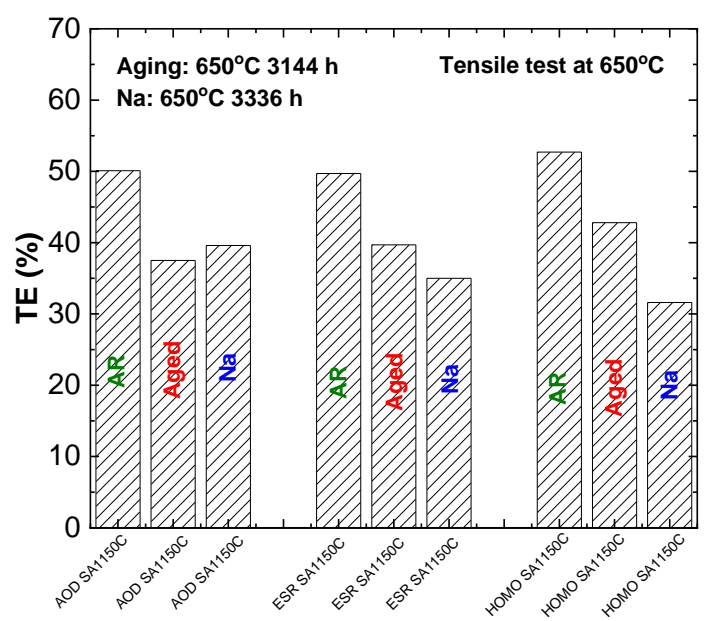

(g)

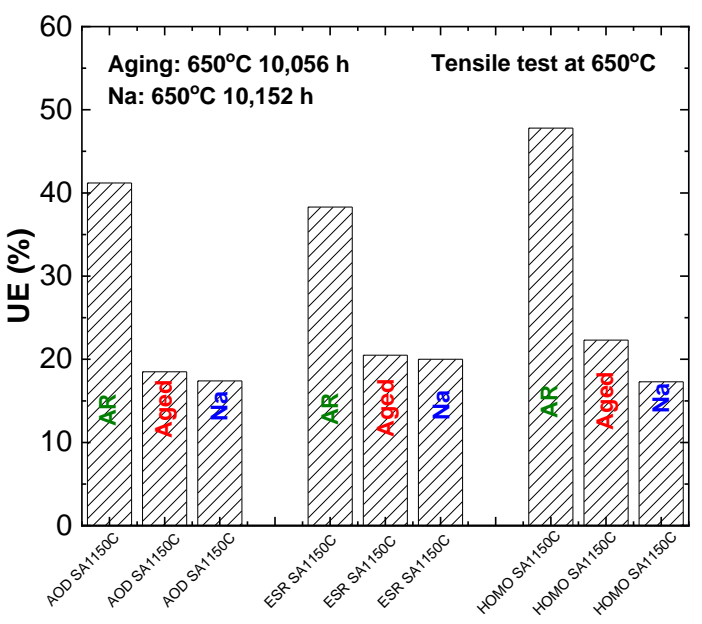

(f)

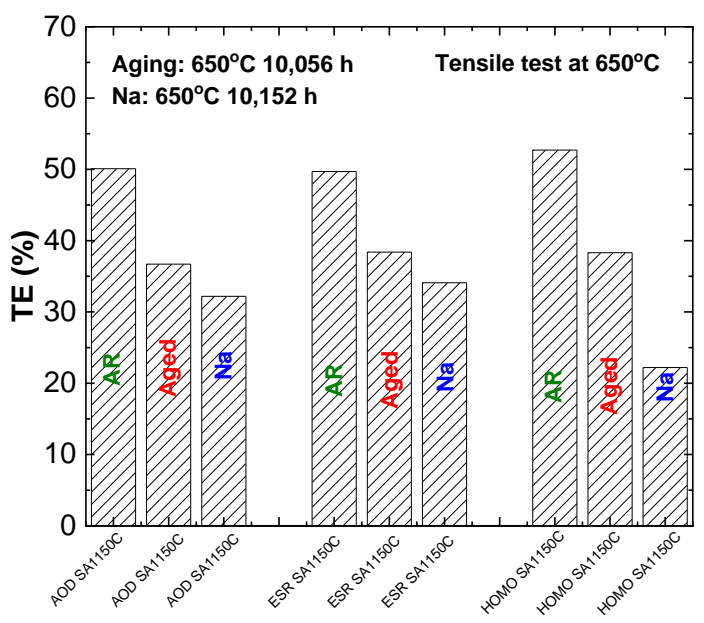

(h)

Figure 11. Comparison of yield stress, ultimate tensile strength, uniform elongation and total elongation for $1150^{\circ} \mathrm{C}$-solution-annealled A709 $\mathrm{H} 58776$. 


\section{Summary}

Sodium exposure tests were conducted on the first commercial heat, H58776 of A709 steel. Six different processing and heat treatment conditions were investigated, including three processing conditions, namely, Argon-Oxygen-Decarburization (AOD), Electro-slag Remelting (ESR), and Electro-slag Remelting with subsequent homogenization (HOMO), and two heat treatment conditions, i.e. solution annealing at $1100^{\circ} \mathrm{C}\left(\mathrm{SA} 1100^{\circ} \mathrm{C}\right)$ or $1150^{\circ} \mathrm{C}\left(\mathrm{SA} 1150^{\circ} \mathrm{C}\right)$. Specimens of AOD-SA $1100^{\circ} \mathrm{C}$, AOD-SA $1150^{\circ} \mathrm{C}$, ESR-SA $1100^{\circ} \mathrm{C}$, ESR-SA $1150^{\circ} \mathrm{C}, \mathrm{HOMO}-$ $\mathrm{SA} 1100^{\circ} \mathrm{C}$, and $\mathrm{HOMO}-\mathrm{SA} 1150^{\circ} \mathrm{C}$ were tested in sodium at $650^{\circ} \mathrm{C}$ and for times up to $10,152 \mathrm{~h}$. Specimens in the AOD-SA $1100^{\circ} \mathrm{C}$ and AOD-SA $1150^{\circ} \mathrm{C}$ conditions were also tested in sodium at 550 and $600^{\circ} \mathrm{C}$. Parallel thermal aging experiments were carried out for comparison with sodium exposure tests to separate the thermal and sodium effects. It was found that

- A709 H58776 generally showed a weight loss after sodium exposures at $650^{\circ} \mathrm{C}$ except a few data points of the ESR-SA $1100^{\circ} \mathrm{C}$ specimens. The corrosion rate showed large variations in the initial stage and decreased with increasing exposure time. Long-term exposure tests are needed to determine its steady-state corrosion rate.

- The AOD-SA $1100^{\circ} \mathrm{C}$ and $\mathrm{HOMO}-\mathrm{SA} 1100^{\circ} \mathrm{C}$ specimens showed similar tensile responses after thermal or sodium exposures at $650^{\circ} \mathrm{C}$. The yield stress increased, the ultimate tensile strength decreased, and the uniform and total elongations were reduced after thermal or sodium exposures. A longer exposure time had a minimal effect on the tensile strength but further reduced the tensile ductility. The sodium-exposed specimens had higher tensile strength than the thermally-aged specimens. In contrast, the ESR-SA $1100^{\circ} \mathrm{C}$ specimens showed an increase in the yield stress and the ultimate tensile strength after thermal or sodium exposures at $650^{\circ} \mathrm{C}$ and $\sim 10,000 \mathrm{~h}$.

- The AOD-SA $1150^{\circ} \mathrm{C}$ and ESR-SA $1150^{\circ} \mathrm{C}$ specimens showed similar tensile behavior after thermal or sodium exposures at $650^{\circ} \mathrm{C}$. Thermal or sodium exposures at $650^{\circ} \mathrm{C}$ increased the yield stress, decreased the ultimate tensile strength, and reduced uniform and total elongations. There were minimal differences in tensile properties between the sodium-exposed and thermally-aged specimens after an $\sim 3000 \mathrm{~h}$ exposure. After an exposure for $\sim 10,000 \mathrm{~h}$ the sodium-exposed specimens showed higher yield stress and ultimate tensile strength and lower uniform and total elongations than the thermally-aged specimens. For the HOMO-SA $1150^{\circ} \mathrm{C}$ specimens, thermal or sodium exposures at $650^{\circ} \mathrm{C}$ significantly increased the yield stress but had a minimal effect on the ultimate tensile strength. Both uniform and total elongations were significantly reduced at an exposure time of $\sim 3,000 \mathrm{~h}$, and they were further reduced after an exposure of $\sim 10,000 \mathrm{~h}$. The sodium-exposed specimens had lower tensile ductility than the thermally-aged specimens.

- Before exposure, the stress-strain curves of the specimens in all six processing-heat treatment conditions showed serrations indicating the dynamic aging effect at $650^{\circ} \mathrm{C}$. Thermal aging or sodium exposures at $650^{\circ} \mathrm{C}$ after $\sim 10,000 \mathrm{~h}$ completely removed the serrations of the flow curves in A709 H58776, indicating strong precipitation during thermal or sodium exposures.

Longer-term sodium exposure tests are needed to determine the steady-state corrosion rates in sodium for A709 H58776 and fully understand the influence of sodium exposures on its mechanical performance. 


\section{Acknowledgement}

The research was sponsored by the U.S. Department of Energy, under Contract No. DEAC02-06CH11357 with Argonne National Laboratory, managed and operated by UChicago Argonne LLC. Programmatic direction was provided by the Office of Nuclear Reactor Deployment of the Office of Nuclear Energy (NE). The authors gratefully acknowledge the support provided by Brian Robinson of DOE-NE, Federal Manager, Advanced Reactor Technologies (ART) Program, Fast Reactors Campaign, Sue Lesica of DOE-NE, Federal Manager, ART Advanced Materials, Robert Hill of Argonne National Laboratory (ANL), National Technical Director, ART Fast Reactors Campaign, and T.-L. Sham of ANL, Technology Area Lead, ART Advanced Materials. Materials were provided by the Oak Ridge National Laboratory. D. L. Rink and Joe Listwan are thanked for loop operation and monitoring, specimen preparation and handling, post-exposure measurements and tensile tests. Yoichi Momozaki is thanked for loop safety and maintenance.

\section{References}

[1] Meimei Li, K. Natesan, Y. Momozaki, D. L. Rink, W. K. Soppet, andJ. T. Listwan, "Report on sodium compatibility of advanced structural materials," ANL-ARC-205, September 2011.

[2] Unpublished information. 


\section{Argonne}

Nuclear Science and Engineering Division

Argonne National Laboratory

9700 South Cass Avenue

Lemont, IL 60439

www.anl.gov

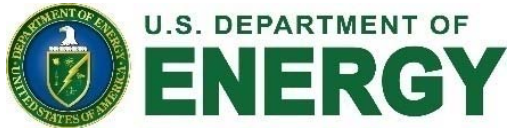

Argonne National Laboratory is a U.S. Department of Energy laboratory managed by UChicago Argonne, LLC 